\title{
Production of fuel-cell grade hydrogen by sorption enhanced water gas shift reaction using Pd/Ni-Co catalyst
}

\author{
Tayyaba Noor ${ }^{\mathrm{a}}$, María V. Gil ${ }^{\mathrm{b}}$, De Chen ${ }^{\mathrm{a}, *}$ \\ a Department of Chemical Engineering, Norwegian University of Science and \\ Technology, Sem Scelands vei 4, Trondheim, NO-7491, Norway \\ ${ }^{\mathrm{b}}$ Instituto Nacional del Carbón, INCAR-CSIC, Apartado 73, 33080 Oviedo, Spain
}

\begin{abstract}
It has been demonstrated both thermodynamically and experimentally that fuel-cell grade hydrogen can be produced by a one-step sorption enhanced water gas shift (SEWGS) process at about $500{ }^{\circ} \mathrm{C}$, where the water gas shift (WGS) catalyst and the $\mathrm{CO}_{2}$ sorbent are highly integrated. A synthetic $\mathrm{CaO}$-based mixed oxide sorbent was also assessed, which showed a good $\mathrm{CO}_{2}$ capture capacity and stability in the cyclic operation of the SEWGS reaction. Catalysts play a significant role in CO conversion via WGS, methanation and methane steam reforming reactions. A Pd promoted Ni-Co catalyst $(1 \% \mathrm{Pd} / 20 \% \mathrm{Ni}-20 \% \mathrm{Co})$ derived from hydrotalcite-like material (HT) showed a high activity for WGS and methane steam reforming. The methanation activity was further reduced on $30 \% \mathrm{Ni}-10 \% \mathrm{Co}$. There exists an optimum temperature $\left(500{ }^{\circ} \mathrm{C}\right)$ for hydrogen production by the SEWGS process, where it is kinetically limited by the WGS reaction at low temperatures $\left(425-475^{\circ} \mathrm{C}\right)$ and it is thermodynamically unfavorable at higher temperatures $\left(475-550^{\circ} \mathrm{C}\right)$. The challenges for hydrogen production by SEWGS at high $\mathrm{CO}$ pressures were also demonstrated, where $\mathrm{CO}$ pressure has shown a negative
\end{abstract}

\footnotetext{
* Corresponding author. Tel.: +47 73593149; fax: +47 73595047.

E-mail address: chen@nt.ntnu.no (D. Chen).
} 
influence on WGS activity. An induction period was observed, which can be reduced by improving catalyst activity and by adding hydrogen to the reactant mixture.

Keywords: CO conversion, Fuel cells, Hydrogen, Pd/Ni-Co-hydrotalcite catalyst, Sorption enhanced water gas shift

\section{Introduction}

Hydrogen is an environmentally friendly and clean energy carrier for a sustainable energy system. In the last few decades, much research has been focused on the study of the benefits and challenges of establishing a cost-effective hydrogen economy. Currently, global hydrogen production comes from natural gas (48\%), oil (30\%) and coal (18\%), water electrolysis accounting for only 4\% [1]. Hydrogen has been widely used for the production of ammonia fertilizers via the Haber process, for methanol synthesis and for conversion of heavy petroleum sources to lighter fractions via hydrocracking [2]. The worldwide demand for hydrogen is expected to increase in the future, not only for conventional industrial uses, but also for clean energy generation such as by means of fuel cells. The development of less expensive methods of producing pure hydrogen is needed to achieve a hydrogen economy.

Literature studies show that by the year 2030 , about $10 \%$ of the worldwide yearly energy consumption will be derived from the water gas shift (WGS) reaction $[3,4]$. The WGS reaction is extensively used to increase the $\mathrm{H}_{2}$ content in the synthesis gas containing $\mathrm{CO}, \mathrm{H}_{2}, \mathrm{CO}_{2}$ and $\mathrm{H}_{2} \mathrm{O}$, which can be generated from the reforming of hydrocarbons from fossil fuels, coal and biomass [5]. To eliminate $\mathrm{CO}$ from the synthesis gas, the WGS reaction plays a vital role in further downstream industrial 
practices, e.g. production of hydrogen, ammonia, methanol and several other chemicals [6]. The $\mathrm{CO}$ reacts with $\mathrm{H}_{2} \mathrm{O}$ to produce $\mathrm{CO}_{2}$ and $\mathrm{H}_{2}$ through the reaction shown in Equation (1):

$\mathrm{CO}_{(\mathrm{g})}+\mathrm{H}_{2} \mathrm{O}_{(\mathrm{g})} \leftrightarrow \mathrm{H}_{2(\mathrm{~g})}+\mathrm{CO}_{2(\mathrm{~g})} \quad \Delta \mathrm{H}^{0}=-41.2 \mathrm{~kJ} \mathrm{~mol}^{-1}$

It is a reversible and moderately exothermic reaction. Lower temperature thermodynamically favors the $\mathrm{CO}$ conversion. For reaching a high process effectiveness, the shift reaction is industrially performed in two stages, i.e., high temperature shift $\left(300-500{ }^{\circ} \mathrm{C}\right)$ followed by a low temperature shift $\left(180-250{ }^{\circ} \mathrm{C}\right)$. The high temperature reactor converts bulk $\mathrm{CO}$ from $\sim 15 \%$ to $\sim 3 \%$ and the low temperature unit further reduces the CO level to less than $0.4 \%[7,8]$. However, in order to produce high-purity $\mathrm{H}_{2}$, additional purification processes are required, such as the pressure swing adsorption (PSA) process. More than $22 \%$ of the cost of producing a purified hydrogen stream comes from the $\mathrm{CO}_{2}$ separation process carried out to increase the hydrogen purity in the exhaust gas, as additional energy and equipment are required [9]. The WGS reaction has also acquired major importance in fuel processing as a $\mathrm{CO}$ removal method in hydrogen production for fuel cells. Low temperature proton exchange membrane (PEM) fuel cells [10] require very low CO levels $(<10 \mathrm{ppm})$ in the $\mathrm{H}_{2}$-rich gas stream in order to suppress the poisoning effect of $\mathrm{CO}$ to the PEM fuel cell catalysts. Production of highly pure hydrogen is of paramount importance for overcoming the $\mathrm{CO}$ poisoning problem. In addition to the WGS reaction, a preferential oxidation (PrOx) step is usually implemented in fuel processing, in which most of the residual $\mathrm{CO}$ is oxidized to $\mathrm{CO}_{2}$. However, a more energy effective technology for production of highly pure hydrogen is extremely desired for using in PEM fuel cells. 
Hydrogen production by "sorption enhanced" processes is one of the most promising approaches for one-step production of high-purity hydrogen which could greatly simplify the process, increase the energy efficiency and lower the cost, as reviewed by Harrison [11], Barelli et al. [12], as well as Chen and He [13]. The sorption enhanced concept is based on the Le Chatelier's principle, i.e., in an equilibrium-limited reaction, the shift of the forward reaction to the product side can be enhanced by selective removal of a reaction product from the reaction mixture. With the aim of avoiding a further purification step in hydrogen production, this concept has been applied to the WGS reaction by several researchers $[14,15]$ by employing a $\mathrm{CO}_{2}$ sorbent which captures the $\mathrm{CO}_{2}$ from the gas phase achieving enhanced yield and conversion values, so that a stream of pure $\mathrm{H}_{2}$ can be produced.

In the sorption enhanced water gas shift (SEWGS) process, a mixture of a $\mathrm{CO}_{2}$ sorbent and a WGS catalyst is installed in a single unit. SEWGS can be divided into two categories, mediate-temperature one $\left(250-350^{\circ} \mathrm{C}\right)$ on modified hydrotalcites, and hightemperature one on $\mathrm{CaO}$ and other mixed oxides sorbents $\left(400-650{ }^{\circ} \mathrm{C}\right)$. The operating temperature depends mostly on thermodynamic properties of the $\mathrm{CO}_{2}$ acceptors. For mediate-temperature SEWGS reaction, hydrotalcites are the commonly chosen sorbents, although their $\mathrm{CO}_{2}$ adsorption capacity is relatively low (1-2 wt\%) and adsorption/desorption kinetics is poor at the reaction and regeneration conditions. Enhanced hydrogen production along with almost 100\% CO conversion has been illustrated by the SEWGS process at $400{ }^{\circ} \mathrm{C}$ on potassium-promoted hydrotalcite-based materials as $\mathrm{CO}_{2}$ acceptors and commercially available iron-chromium-based shift catalysts [16,17]. Jang et al. [18] recently reported the use of $\mathrm{K}_{2} \mathrm{CO}_{3}$-promoted hydrotalcite and $\mathrm{Na}_{2} \mathrm{O}$-promoted alumina as $\mathrm{CO}_{2}$ sorbents along with a commercial low 
temperature shift catalyst in the SEWGS process at $400{ }^{\circ} \mathrm{C}$ to generate high-purity hydrogen. Fuel-cell grade hydrogen $(<10-20$ ppm $\mathrm{CO})$ has been also obtained by Beaver et al. [19] from the SEWGS process at reaction temperatures of $200{ }^{\circ} \mathrm{C}$ using $\mathrm{K}_{2} \mathrm{CO}_{3}$ promoted hydrotalcite and $\mathrm{Na}_{2} \mathrm{O}$-promoted alumina sorbents and a commercial WGS catalyst. Hydrotalcites with alkaline metal oxides promotion enhanced the $\mathrm{CO}_{2}$ capture. However, alkaline metals such as $\mathrm{Na}$ and $\mathrm{K}$ are mobile in steam, so they have been reported as poisons which deactivate the steam reforming catalysts [20]. However, such effects have not been addressed in the SEWGS with alkaline promoted hydrotalcites and cycle stability of SEWGS using alkaline oxides promoted hydrotalcites has not been reported.

On the other hand, $\mathrm{CaO}$-based sorbents are typically a common choice for $\mathrm{CO}_{2}$ capture purposes along with commercial catalysts at high temperatures [15]. The major advantages of CaO-based materials are that they exhibit fairly good kinetics and excellent adsorption capacity at high temperatures $(20-50 \mathrm{wt} \%)$, together with that their raw materials (i.e., limestone or dolomite) are abundant and inexpensive. The sorption reaction using $\mathrm{CaO}$ as sorbent material is represented by Equation (2), whereas the overall SEWGS is expressed as shown in Equation (3):

$$
\begin{array}{ll}
\mathrm{CaO}_{(\mathrm{s})}+\mathrm{CO}_{2(\mathrm{~g})} \leftrightarrow \mathrm{CaCO}_{3(\mathrm{~s})} & \Delta \mathrm{H}^{0}=-178 \mathrm{~kJ} \mathrm{~mol}^{-1} \\
\mathrm{CO}_{(\mathrm{g})}+\mathrm{H}_{2} \mathrm{O}_{(\mathrm{g})}+\mathrm{CaO}_{(\mathrm{s})} \leftrightarrow \mathrm{CaCO}_{3(\mathrm{~s})}+\mathrm{H}_{2(\mathrm{~g})} & \Delta \mathrm{H}^{0}=-219 \mathrm{~kJ} \mathrm{~mol}^{-1}
\end{array}
$$

The earliest concept of the SEWGS process using CaO-based sorbents (dolomite), traces back in 1931, when Gluud et al. [21] proposed to carry out the SEWGS reaction at temperatures of $300-600{ }^{\circ} \mathrm{C}$, assuming that $\mathrm{CaO}$ plays an active role in the $\mathrm{CO}_{2}$ capture shifting the reaction towards forward direction. Han and Harrison [22] in 1994 confirmed the enhancement of the reaction efficiency at $500-600{ }^{\circ} \mathrm{C}$ using dolomite as 
$\mathrm{CO}_{2}$ sorbent without any catalyst in SEWGS experiments. The high-temperature SEWGS is superior to the mediate-temperature SEWGS regarding to the process energy efficiency, due to a smaller gap of the temperature in relation to the synthesis gas production [23]. In addition, higher rates for both WGS and carbonation reactions as well as high $\mathrm{CO}_{2}$ capture capacity of $\mathrm{CaO}$-based materials could significantly reduce the reactor value required.

Ramkumar and Fan [24] also demonstrated the enhanced hydrogen yield from coalderived syngas using a synthetic $\mathrm{CaO}$ sorbent and a commercial high-temperature WGS catalyst and they obtained a hydrogen purity $>99 \%$ at high pressures. The presence of WGS catalyst clearly improved the hydrogen production, particularly at low pressures. Unfortunately their reactor system had a relatively large contribution to WGS reaction, making it difficult to analyze the effects of catalyst in SEWGS. In addition, cyclic stability of the sorbents has not been reported. Müller et al. [14] compared natural and synthetic CaO-based sorbents in SEWGS experiments at $650{ }^{\circ} \mathrm{C}$, revealing a constant decline in the hydrogen production over a number of cycles using limestone. Synthetic calcium magnesium acetate was found to be more stable than the natural $\mathrm{CaO}$-based sorbents. The key drawback of $\mathrm{CaO}$-based sorbents is that the chemically reactive $\mathrm{CaO}$ is a weak, friable material with poor cycle stability. Calcined dolomite $(\mathrm{CaO} / \mathrm{MgO})$ has been proved to be a good natural material for $\mathrm{CO}_{2}$ capture $[13,25,26]$ which has better multi-cycle properties compared to limestone [27,28]. However, dolomites suffer serious deactivation during cycles. The improvement in the properties of $\mathrm{CaO}$-based sorbents for being used in SEWGS processes still represents an important challenge. Large efforts have been devoted to develop new synthetic $\mathrm{CO}_{2}$ solid sorbents for hightemperature sorption enhanced processes, such as lithium silicates and zirconates [29], 
sodium zirconate [30,31] and synthetic CaO-based solid sorbents [32,33]. These synthetic $\mathrm{CO}_{2}$ acceptors were found to significantly improve the cyclic behavior at high temperatures, so they have become highly attractive for being used in SEWGS processes.

Apart from the sorbent material, highly active catalysts are also crucial for obtaining high yield and high purity of hydrogen, in particular fuel-cell grade hydrogen, from sorption enhanced reactions. Few literature reports are available on the study of catalysts under SEWGS conditions and most likely industrial catalysts are employed. The performance of $\mathrm{Fe}-\mathrm{Cr}$ and Co-Mo as promising catalysts under SEWGS conditions at $400{ }^{\circ} \mathrm{C}$ was illustrated by van Dijk et al. [34]. The typically used industrial catalyst for the high-temperature WGS reaction is usually a combination of $\mathrm{Fe}_{2} \mathrm{O}_{3}$ and $\mathrm{Cr}_{2} \mathrm{O}_{3}$ [35], but due to the toxic and carcinogenic issues of chromium, it is highly desirable to develop an alternative chromium-free catalyst for being used in this process. Some chromium-free iron-based catalysts containing $\mathrm{Al}, \mathrm{Ni}, \mathrm{Co}$ and $\mathrm{Zn}$ have been studied with satisfactory results $[36,37]$. The effectiveness in the $\mathrm{CO}$ conversion on different metals supported on alumina at high temperatures $\left(300-1000^{\circ} \mathrm{C}\right)$ has been found to follow the following order: $\mathrm{Ni}>\mathrm{Ru}>\mathrm{Rh}>\mathrm{Pt}>\mathrm{Pd}$ [38]. The commercial $\mathrm{Cu} / \mathrm{ZnO} / \mathrm{Al}_{2} \mathrm{O}_{3}$ catalyst is widely used in industrial fields for the low-temperature WGS reaction, but other materials like ceria-supported transition metals catalysts have been studied showing high activities for the WGS reaction [39].

Nickel-based catalysts have been also studied for both high- and low-temperature WGS reaction. Addition of $\mathrm{K}$ as promoter in Ni-based catalysts improved the activity and selectivity for the WGS reaction [40]. Ni-based catalysts were also studied on different supports like $\mathrm{SiO}_{2}$ and $\mathrm{Al}_{2} \mathrm{O}_{3}$ [41]. Previous works in our research group showed high 
activity and stability for the $\mathrm{H}_{2}$ production from biomass reforming using a bimetallic Ni-Co catalyst [42-44]. A Ni-Co catalyst derived from hydrotalcite-like material (HT) was also synthesized and studied in sorption enhanced steam reforming (SESR) of ethanol [45] and glycerol [46]. A previous effort carried out by our research group concerning sorption enhanced studies of the WGS reaction was based on biosyngas [47] using a $30 \% \mathrm{Ni}-10 \% \mathrm{Co} \mathrm{HT}$ catalyst, showing that the process was highly proficient to produce relatively pure $\mathrm{H}_{2}$, but the $\mathrm{CO}$ content was still too high for direct use in PEM fuel cells.

The present work is focused on the development of new catalyst and sorbent materials appropriate for using in the high-temperature SEWGS reaction aiming for one-step production of fuel-cell grade high-purity hydrogen $(<10 \mathrm{ppm} \mathrm{CO})$ with low concentrations of $\mathrm{CO}_{2}$ and methane, which has not been previously reported in literature. $1 \% \mathrm{Pd} / 20 \% \mathrm{Ni}-20 \% \mathrm{Co}, 20 \% \mathrm{Ni}-20 \% \mathrm{Co}$ and $30 \% \mathrm{Ni}-10 \% \mathrm{Co}$ HT-derived catalysts were used to study the effect of the catalyst composition $(\mathrm{Co} / \mathrm{Ni}$ ratios $)$ and that of the addition of Pd in the catalyst on the SEWGS reaction, aiming for high WGS activity and low methanation activity. Calcined dolomite and a synthetic nanocrystalline mixed oxide $(\mathrm{CaCeZr})$ were studied as $\mathrm{CO}_{2}$ sorbent materials in the SEWGS process in order to achieve a better sorbent stability. The operating temperature, steam/CO ratio and $\mathrm{CO}$ partial pressure in the feed stream were thermodynamically and experimentally assessed in order to obtain pure $\mathrm{H}_{2}$ in the one-step proposed process. An additional objective of the present work is to gain a better understanding of the SEWGS reaction, which integrates sorption enhanced and reforming reactions. 


\section{Experimental}

Several Ni-Co hydrotalcite-like materials (HT) have been used as catalysts in this work: 20\%Ni-20\%Co HT, 30\%Ni-10\%Co HT and 1\%Pd/20\%Ni-20\%Co HT. The Ni-Co HT catalysts were prepared by co-precipitation of $\mathrm{Ni}\left(\mathrm{NO}_{3}\right)_{2} \cdot 6 \mathrm{H}_{2} \mathrm{O}, \mathrm{Co}\left(\mathrm{NO}_{3}\right)_{3} \cdot 6 \mathrm{H}_{2} \mathrm{O}$, $\mathrm{Mg}\left(\mathrm{NO}_{3}\right)_{3} \cdot 6 \mathrm{H}_{2} \mathrm{O}$ and $\mathrm{Al}\left(\mathrm{NO}_{3}\right)_{3} \cdot 9 \mathrm{H}_{2} \mathrm{O}$. The stoichiometric ratio of cations was chosen to yield $40 \mathrm{wt} \%$ total metal loading of $\mathrm{Ni}$ and $\mathrm{Co}$, giving materials with the nominal compositions of $20 \% \mathrm{Ni}-20 \% \mathrm{Co}$ and $30 \% \mathrm{Ni}-10 \% \mathrm{Co}$. The collected precipitates were washed, dried and calcined at $600{ }^{\circ} \mathrm{C}$ for $6 \mathrm{~h}$ to yield the Ni-Co HT. A detailed description of the Ni-Co HT catalyst preparation and characterization was reported elsewhere $[43,48]$. The $20 \% \mathrm{Ni}-20 \% \mathrm{Co} \mathrm{HT}$ catalyst was used as precursor of the Ni-Co HT catalyst promoted with $\mathrm{Pd}, 1 \% \mathrm{Pd} / 20 \% \mathrm{Ni}-20 \% \mathrm{Co} \mathrm{HT}$, which was prepared by the incipient wetness method. After calcination, the $20 \% \mathrm{Ni}-20 \% \mathrm{Co}$ HT was impregnated with a $1 \%(\mathrm{w} / \mathrm{w})$ loading of $\mathrm{Pd}$. The Pd solution was prepared by dissolving $\mathrm{PdCl}_{2}$ into two equivalents of $\mathrm{HCl}$ and diluting in ethanol to the desired concentration. The sample was then dried for $14 \mathrm{~h}$ at $100^{\circ} \mathrm{C}$ and calcined at $500{ }^{\circ} \mathrm{C}$ for $1 \mathrm{~h}$. Finally, the calcined catalysts were pelletized, ground and sieved to the desired particle size $(250-500 \mu \mathrm{m})$. Two $\mathrm{CO}_{2}$ sorbents were used in the SEWGS experiments in the present work: calcined dolomite and a CaO-based mixed oxide (CaCeZr). ARCTIC dolomite, precursor of the $\mathrm{CO}_{2}$ acceptor, was supplied by Franefoss Miljøkalk As, Norway. It had a purity of approximately $98.5 \mathrm{wt} \% \mathrm{CaMg}\left(\mathrm{CO}_{3}\right)_{2}$ and no sulfur according to $\mathrm{X}$-ray fluorescence analysis. The dolomite sample was calcined in an air flow at $750{ }^{\circ} \mathrm{C}$ for $4 \mathrm{~h}$ prior to its application as $\mathrm{CO}_{2}$ sorbent. Its initial maximum capacity for $\mathrm{CO}_{2}$ capture was estimated at ca. $46 \%$ (weight of captured $\mathrm{CO}_{2} /$ weight of sorbent). The second sorbent was a calcium-based mixed oxide developed to study its stability and performance in the 
SEWGS process. The mixed oxide $\mathrm{CaCeZr}$ was prepared by using the spray drying technique [49]. The precursor slurry was prepared by mixing the metal salts, calcium acetate (Fluka), cerium nitrate (Fluka) and zirconium nitrate (Fluka), at a molar ratio of 10:1:1 in deionized water. The solution was stirred overnight and the slurry was subjected to spray drying (Buchi, Mini Spray drier, B-191) at $200{ }^{\circ} \mathrm{C}$. The pump speed was adjusted to reach a solution intake of $8 \mathrm{~mL} \mathrm{~min}^{-1}$ and the air flow was $4.3 \mathrm{~m} \mathrm{~s}^{-1}$. The product obtained after spray drying was calcined at $750{ }^{\circ} \mathrm{C}$ for $4 \mathrm{~h}$ under air flow and it was ready to be used as sorbent material.

$\mathrm{XRD}$ and nitrogen physisorption analyses were carried out in order to characterize catalyst and sorbent materials. The crystalline structure of the materials was studied by powder X-ray diffraction analysis on a Siemens IFFRACplus-D5005 diffractometer. Nitrogen physisorption measurements were performed on a Micromeritics Tristar 3000 at $-196^{\circ} \mathrm{C}$ after outgassing the samples overnight under vacuum at $100{ }^{\circ} \mathrm{C}$ before adsorption. The surface area was calculated using the BET equation in the relative pressure interval ranging from 0.01 to 0.30 . The adsorption average pore width (4 V/A) was estimated by the Barret-Joyner-Halenda $(\mathrm{BJH})$ method provided by the Micromeritics Tristar 3000 built-in software.

The SEWGS experiments were carried out in a Microactivity-Reference reactor (PID Eng\&Tech, Spain). The schematic diagram of the experimental setup is shown in Fig. 1. A mixture of catalyst and sorbent was place in a fixed bed quartz reactor (inner diameter $14 \mathrm{~mm}$ ). Prior to the experiment, the catalyst was activated by reduction at $670{ }^{\circ} \mathrm{C}$ for $10 \mathrm{~h}$ under a flowing gas mixture of $50 \mathrm{vol} \% \mathrm{H}_{2}-\mathrm{He}$ (total flow $200 \mathrm{~mL} \mathrm{~min}^{-1}$ ) and the reactor was then purged with inert gas and cooled down to the desired temperature. The reaction temperature was monitored by means of a thermocouple inserted in the bed. All 
the experiments were carried out at atmospheric pressure in the temperature range of $425{ }^{\circ} \mathrm{C}-550{ }^{\circ} \mathrm{C}$ to study the effect of the reaction temperature. The steam/CO ratio and the $\mathrm{CO}$ partial pressure in the feed stream were varied in the different experiments in order to evaluate their effect on the SEWGS reaction. For the SEWGS experiments, a vapor mixture of $\mathrm{CO}$ and $\mathrm{H}_{2} \mathrm{O}$ was swept by $\mathrm{He}$ flow into the reactor. Gases were delivered by Bronkhorst mass flow controllers and liquid water was introduced by a Gilson ${ }^{\circledR}$ HPLC pump and vaporized by means of an evaporator before being introduced into the reactor. The reactor effluent was cooled down through a condenser (Peltier) and an ice-cooled bath. The exiting gas was analyzed with an online Agilent 3000 Micro GC equipped with a Molsieve and a Plot U columns and a TCD detector. The Micro GC was calibrated employing a standard gas mixture at periodical intervals and the detection limit of the equipment is $0.001 \mathrm{vol} \%$. The SEWGS reaction occurred until the $\mathrm{CO}_{2}$ sorbent was saturated and it lost the capacity for $\mathrm{CO}_{2}$ removal. For the study of the sorbent stability, after the SEWGS experiment the feed was switched to inert gas for sorbent regeneration at $750{ }^{\circ} \mathrm{C}$ for about $4 \mathrm{~h}$ and the reaction and regeneration stages were repeated cyclically.

The product gas distribution was based on the water-free composition of the gas effluent. The results were expressed as molar fraction of $\mathrm{H}_{2}, \mathrm{CO}, \mathrm{CH}_{4}$ and $\mathrm{CO}_{2}$. The capture capacity of the $\mathrm{CaCeZr}$ mixed-oxide sorbent in the cyclic operation was calculated by Equation (4) and it was expressed as grams of $\mathrm{CO}_{2}$ captured per gram of sorbent using Equation (5).

$$
\begin{aligned}
& \mathrm{N}_{\mathrm{CO}_{2}}=\int_{0}^{t 1}\left(\mathrm{FCO}_{2}, \text { tot }-\mathrm{FCO}_{2, t}\right) d t \\
& \% \text { Capacity }=\left[\frac{\mathrm{g} \mathrm{CO}_{2}}{\mathrm{~g} \text { calcined sorbent }}\right] \times 100
\end{aligned}
$$


Here, $F_{\mathrm{CO} 2 \text {,tot }}$ represents the average value of $\mathrm{CO}_{2}$ flow rate during the course of the conventional water gas shift reaction, $F_{\mathrm{CO} 2, t}$ represents the $\mathrm{CO}_{2}$ flow rate at time $t$ and $t_{1}$ represents the time point where the $\mathrm{CO}_{2}$ content in the gas effluent did not increase any more after the breakthrough started.

Finally, a thermodynamic analysis of the SEWGS process has been conducted under different reaction conditions. The equilibrium compositions were obtained by minimizing the total Gibbs free energy of the reaction system. Aspen Plus 7.2 software (Aspentech) was used for calculations. The R-Gibbs reactor was specified as the reaction system, where the Peng-Robinson property method predicts the thermodynamic behavior of the system. According to the obtained results for the equilibrium prediction under sorption enhanced conditions, the present species at concentrations higher than $10^{-4} \mathrm{~mol} \%$ were $\mathrm{H}_{2}, \mathrm{CO}, \mathrm{CO}_{2}, \mathrm{CH}_{4}, \mathrm{H}_{2} \mathrm{O}, \mathrm{CaO}$ and $\mathrm{CaCO}_{3}$. Ethane, ethylene, acetylene and solid carbon (graphite) were also included in the product pool, but their concentrations in the equilibrium stream were not great enough to be considered as effective products. Product mole fractions are given on a dry basis.

\section{Results and Discussion}

\subsection{Sorption-enhanced water gas shift process}

A typical profile of gas product composition as a function of time on stream after the experimental SEWGS reaction process on $1 \% \mathrm{Pd} / 20 \% \mathrm{Ni}-20 \% \mathrm{Co}$ at $425{ }^{\circ} \mathrm{C}$ is shown in Fig. 2. The evolution of the gas effluent compositions in the sorption enhanced process can be typically divided in three stages: pre-breakthrough, breakthrough and postbreakthrough $[45,50,51]$. During the pre-breakthrough stage, the calcined dolomite effectively captured $\mathrm{CO}_{2}$ and thereby its concentration was very low $(0.01 \mathrm{~mol} \%)$. At 
the same time, the WGS reaction was shifted towards the product side by the $\mathrm{CO}_{2}$ removal and $\mathrm{H}_{2}$ concentration was increased to high efficiency $(99.28 \mathrm{~mol} \%)$, whereas $\mathrm{CO}$ concentration was below the detection limit of the Micro $\mathrm{GC}$ and $\mathrm{CH}_{4}$ concentration $(0.70 \mathrm{~mol} \%)$ was low. In the breakthrough region, the $\mathrm{CaO}$ sorbent became saturated, which was indicated by a rapid rise in $\mathrm{CO}_{2}$ concentration and a reduction in the $\mathrm{H}_{2}$ concentration. In the post-breakthrough region, the $\mathrm{CO}_{2}$ capture by the sorbent was negligible and conventional WGS reaction (without $\mathrm{CO}_{2}$ removal) was assumed to occur. The corresponding $\mathrm{H}_{2}$ concentration was considerably lower than that during the active $\mathrm{CO}_{2}$-capture stage. These results demonstrated that dolomite as $\mathrm{CaO}$-based solid $\mathrm{CO}_{2}$ acceptor is suitable for SEWGS, which effectively removed the $\mathrm{CO}_{2}$ during the reaction and thus enhanced the performance of WGS for hydrogen production.

\subsection{Effect of reaction temperature on SEWGS}

Temperature is an important parameter in the SEWGS process, since it influences not only the thermodynamic equilibrium of carbonation and WGS reactions but also the rate of the reactions. The SEWGS reaction was conducted at different temperatures at a steam/CO ratio of $4(\mathrm{CO}$ pressure of $12.5 \mathrm{kPa})$ on $1 \% \mathrm{Pd} / 20 \% \mathrm{Ni}-20 \% \mathrm{Co} \mathrm{HT}$. The results are summarized in Table 1 together with the corresponding equilibrium compositions. It should be mentioned that an induction period before the SEWGS reaction was observed using a $\mathrm{CO}$ pressure of 12.5 , which will be discussed later. The steady-state composition after the induction period was taken for the calculation of the concentrations listed in Table 1.

The equilibrium compositions obtained from the thermodynamic calculation (Table 1) showed that the hydrogen concentration decreases and the concentrations of methane, 
$\mathrm{CO}$ and $\mathrm{CO}_{2}$ increase concurrently with increasing the operating temperature. The results are in good agreement with those obtained in the sorption enhanced steam reforming of ethanol [45], as well as glucose and sorbitol [50]. At steam/CO ratio of 4, the $\mathrm{CH}_{4}$ equilibrium concentration was only slightly increased with the temperature. In general, the experimental gas compositions from the SEWGS reaction were found to be rather consistent with the predicted equilibrium values. However, it should be noticed that the experimental $\mathrm{CO}_{2}$ contents are slightly, but systematically lower than the equilibrium ones at different temperatures. It can be possibly ascribed to a possible deviation of thermodynamic properties of dolomites from the pure $\mathrm{CaO}$ used in the calculations. As a result, it possibly also caused slightly higher experimental concentrations of hydrogen at $500{ }^{\circ} \mathrm{C}$ and $525^{\circ} \mathrm{C}$ compared to equilibrium ones. Anyhow, such deviations are within the experimental error range. In addition, the CO concentrations at $450-500{ }^{\circ} \mathrm{C}$ were lower than the equilibrium ones, which are also most likely within the experimental error. The $\mathrm{CO}$ concentration at 475 and $500{ }^{\circ} \mathrm{C}$ was below the GC detection limit.

The experimental results from the SEWGS reaction at $\mathrm{CO}$ pressure of $12.5 \mathrm{kPa}$ (Table 1) indicated that the combination of $\mathrm{CO}_{2}$ capture and WGS reaction yielded a highpurity hydrogen stream $(>99 \%)$ with low CO concentration. However, as mentioned above, the extent of the shift from the equilibrium composition was higher at low temperatures. The $\mathrm{CO}$ concentration increased concurrently with decreasing temperature from $475^{\circ} \mathrm{C}$ to $425^{\circ} \mathrm{C}$, while the $\mathrm{CO}_{2}$ concentration was similar, which could be caused by a lower WGS catalyst activity at lower temperatures. The experimental methane content showed a high dependence on the temperature, which is different from the equilibrium results. The results showed $\mathrm{CH}_{4}$ content decreased with 
increasing temperature up to $500{ }^{\circ} \mathrm{C}$. As a consequence the $\mathrm{H}_{2}$ content increased. It could be result of the unfavorable thermodynamics of the methanation reaction, enhanced WGS and methane reforming, as well as carbonation reaction for more effective removal of $\mathrm{CO}_{2}$ inside the reactor [52], at higher temperatures. The observation is consistent with that found in SESR of ethanol where the larger deviation of the experimental $\mathrm{H}_{2}$ contents from the corresponding equilibrium values was found at lower temperatures $\left(500-525^{\circ} \mathrm{C}\right)$ due to higher $\mathrm{CH}_{4}$ content in the gas product [45]. However, $\mathrm{CH}_{4}$ concentration increased and $\mathrm{H}_{2}$ content decreased with further increasing temperature from $500{ }^{\circ} \mathrm{C}$ (Table 1), which is consistent with the increase in $\mathrm{CO}_{2}$ content. The experimental results at higher temperatures are in good agreement with the thermodynamic prediction. Carbonation of $\mathrm{CaO}$ is less favorable at higher temperatures, which decreased the sorption enhancement on WGS and increased CO concentration, which led to enhanced methanation. It can be therefore concluded that hydrogen production by SEWGS is kinetically limited by the WGS reaction and enhanced methanation at lower temperatures $\left(425-475^{\circ} \mathrm{C}\right)$, while it is thermodynamically unfavorable by the $\mathrm{CO}_{2}$ capture at higher temperatures $\left(475-550^{\circ} \mathrm{C}\right)$ due to reduced sorption enhancement for hydrogen production. There is a minimum $\mathrm{CH}_{4}$ content $(0.01 \%)$ and maximum hydrogen content $(99.93 \%)$ at the optimized temperature of $500{ }^{\circ} \mathrm{C}$.

Since $\mathrm{CO}$ concentrations found in the product gas at 425 and $450{ }^{\circ} \mathrm{C}$ were higher than expected and they deviated from the equilibrium values, two additional SEWGS experiments were performed under the same operating conditions at temperatures of 425 and $450{ }^{\circ} \mathrm{C}$, but using a lower $\mathrm{CO}$ partial pressure in the feed stream $(6.25 \mathrm{kPa})$, in order to check if the $\mathrm{CO}$ concentration in the product gas at low temperature was 
affected by the $\mathrm{CO}$ partial pressure. The $\mathrm{H}_{2} \mathrm{O}$ partial pressure in the feed stream was decreased accordingly to maintain the steam/CO ratio of 4 . It can be noted (Table 1 ) that at relatively low partial pressure of $\mathrm{CO}$ it was possible to fully convert $\mathrm{CO}$ until values below the detection limit of the Micro GC with high hydrogen purity at low temperatures. The results indicated that partial pressure of the reactants in the feed stream affected the product composition, which will be further investigated in the next section.

\subsection{Effect of the steam/CO ratio and CO partial pressure in feed gas on SEWGS}

Steam is often added beyond stoichiometric limit in reforming processes in order to promote hydrogen productivity and to prevent coking. The steam/CO ratio can have a significant impact on the hydrogen production by the SEWGS process. In the present study, the SEWGS reaction was conducted at different steam/CO ratios and CO partial pressures at $425^{\circ} \mathrm{C}$, and the results are summarized in Table 2, together with the corresponding equilibrium compositions. The $\mathrm{H}_{2} \mathrm{O}$ partial pressure in the feed stream $\left(\mathrm{P}_{\mathrm{H} 2 \mathrm{O}}\right)$ was changed accordingly to the $\mathrm{CO}$ partial pressure values in order to maintain the corresponding steam/CO ratio in each experiment, their values being also shown in Table 2 in parentheses.

The steam/CO ratio is expected to have an effect on the gas product composition, since an increase in steam concentration favors hydrogen production by shifting the equilibrium of WGS reaction. The thermodynamic analysis predicts only a slight decrease in hydrogen content from 99.98 to $99.80 \%$ with decreasing steam/CO ratio from 4 to 2 , besides a methane content increase from 0.011 to $0.197 \%$. Taking into account the experiments carried out with low $\mathrm{CO}$ partial pressure in the reactant mixture 
$(6.25 \mathrm{kPa})$, the $\mathrm{H}_{2}$ purity obtained at steam/CO ratio of 2, 3 and 4 showed high values (98.6-99.3\%), whereas a nearly complete conversion of $\mathrm{CO}$ was only found at steam/CO ratios of 3 and 4 . When the steam/CO ratio was reduced to 2 , a low $\mathrm{CO}$ content $(0.01 \%)$ was found in the gas product. On the other hand, when the experiments were performed using higher $\mathrm{CO}$ partial pressure values in the reactant mixture (15.15$21.74 \mathrm{kPa}$ ), the hydrogen purity decreased compared to that obtained with low $\mathrm{CO}$ partial pressure at all the steam/CO ratios studied, the $\mathrm{CO}$ content in the gas product being very high. $\mathrm{CO}_{2}$ content was kept almost unchanged regardless to the $\mathrm{CO}$ pressure and steam/CO ratio, with a value rather close to the equilibrium one, which indicated that the carbonation reaction of $\mathrm{CaO}$ occurred under the conditions studied in Table 2 . Therefore, the results clearly indicated that an increase in CO partial pressure in the feed stream produces a negative effect on the $\mathrm{CO}$ conversion rate, namely negative apparent reaction order of CO. More importantly, this finding points out a challenge for SEWGS at high pressures in terms of catalyst activity at high $\mathrm{CO}$ partial pressure, suggesting that more active catalysts are highly desired.

Results also suggested that catalyst activity was high enough by performing the SEWGS reaction close to the equilibrium at $\mathrm{CO}$ partial pressure of $6.25 \mathrm{kPa}$ with a space velocity WHSV $=3.44 \mathrm{~h}^{-1}$ and low temperature $\left(425^{\circ} \mathrm{C}\right)$. However, the catalyst activity seems to be significantly reduced at high $\mathrm{CO}$ pressure $(12.5 \mathrm{kPa})$ and low temperature. Results suggested that the gas composition was determined kinetically but not thermodynamically. It indicates that a more extensive study of the SEWGS process at high $\mathrm{CO}$ pressure values could be useful to provide kinetic information of the catalysts. Under high $\mathrm{CO}$ pressure conditions, as steam/CO ratio decreased, a strong decrease was also observed in the $\mathrm{H}_{2}$ and $\mathrm{CO}$ contents, while a significant increase was 
observed in the $\mathrm{CH}_{4}$ content. Thus, very high methane concentration (10.24\%) was found at steam/CO of 2. High $\mathrm{CO}$ pressure and low steam/CO ratio obviously enhanced methanation and decreased methane steam reforming simultaneously. He et al. [46] carried out sorption enhanced steam reforming experiments of glycerol and also found lower hydrogen purity at low values of steam-to-glycerol ratio. The authors suspected that carbonaceous species were formed on the catalyst under such conditions, causing deterioration in the catalyst activity, which caused an increase in the methane content at the expense of the hydrogen production. The results highlighted that catalysts with low activity to methanation and high activity to methane steam reforming are required at low temperatures. Summarizing, the results indicated that the partial pressure of the reactants in the feed stream can influence the catalyst activity, and thus the product composition. High CO pressure suppressed catalyst activity not only for WGS but also for methane steam reforming. It can be noted that at relatively low partial pressure of $\mathrm{CO}$ it was possible to fully convert $\mathrm{CO}$ until values below the detection limit of the Micro GC with high hydrogen purity at low temperatures.

The results of SEWGS also will help us to understand why we could get very high hydrogen yield and very low CO content by sorption enhanced reforming of different hydrocarbons and biomass-derived oxygenates on our Ni-Co bimetallic catalysts $[43,45,46]$. The steam reforming and WGS form a sequential reaction, and a high activity of the bimetallic catalyst will keep $\mathrm{CO}$ at low concentrations in the gas phase and thus it will avoid the suppressing effects of the high $\mathrm{CO}$ concentrations. Ideally, steam reforming function and WGS function should be integrated to the highest extent. Therefore, catalyst with a high WGS activity is also essential for the sorption enhanced reforming reactions in order to get high yield of hydrogen. 


\subsection{Effect of the catalyst reduction on SEWGS}

The use of a catalyst in several reaction-regeneration cycles may affect its activity. NiCo catalysts used in continuous cyclic operation usually suffer from a reversible deactivation due to the loss of active sites during the regeneration step by means of oxidation of $\mathrm{Ni}$ and $\mathrm{Co}$ with high concentrations of $\mathrm{CO}_{2}$ or by the oxidative gases added, such as oxygen, forming the corresponding oxides. As a consequence, they require a reduction step before the next cycle. Catalysts that are easily reducible and less sensitive to oxidative treatments at high temperatures are highly desirable to simplify the process. For this purpose, $\mathrm{Pd}$ was selected as a promoter for the Ni-Co catalysts. The presence of $\mathrm{Pd}$ in the Ni-Co catalyst used in the present work could promote the rapid production of $\mathrm{H}_{2}$ which would assist the catalyst reduction, avoiding a reduction step between cycles in sorption enhanced biomass gasification, as suggested by Fermoso et al. [42] in a previous work. The effect of using unreduced $1 \% \mathrm{Pd} / 20 \% \mathrm{Ni}-20 \% \mathrm{Co}$ HT catalyst on the SEWGS reaction was checked by the repetition of one of the experiments at $\mathrm{CO}$ partial pressure of $6.25 \mathrm{kPa}$ after the sorbent regeneration but without the reduction step of the catalyst. Fig. 3 shows the gas product composition as a function of time on stream after the SEWGS reaction using reduced and unreduced $1 \% \mathrm{Pd} / 20 \% \mathrm{Ni}-20 \% \mathrm{Co} \mathrm{HT}$ catalyst for comparison.

The results indicated that the hydrogen purity from the SEWGS process was not affected by the reduction of the catalyst ( $99.8 \mathrm{~mol} \%$ with the reduced catalyst and 99.7 mol $\%$ with the unreduced one). However, in the case of the reduced catalyst, the complete conversion of $\mathrm{CO}$ was achieved, since during the SEWGS reaction $\mathrm{CO}$ concentration was below the detection limit of the Micro GC. However, when unreduced catalyst was used a notable CO concentration (around 0.02 mol \%) was 
detected during the SEWGS process. Therefore, in order to minimize the CO concentration in the gas product stream of the SEWGS process and obtain a high-purity hydrogen gas, the reduction of the catalyst between consecutive cycles of reaction is needed. However, it should be pointed out that the reduction of the Co-Ni catalysts has been significantly improved by the promotion of noble metals, such as $\mathrm{Pd}$, which simplifies the process in order to be used in circulating fluidized bed reactors to produce hydrogen with a low amount of impurities. On the other hand, results indicate that the catalyst is crucial for obtaining high-purity hydrogen by SEWGS, which is consistent with the results reported by Ramkumar and Fan [24].

\subsection{Effect of the catalyst composition on SEWGS}

Since the $\mathrm{CH}_{4}$ concentrations detected in the experiments carried out with high $\mathrm{CO}$ partial pressure values in the feed stream at low temperatures (Tables 1 and 2) were extremely high, one additional SEWGS experiment was performed at $450{ }^{\circ} \mathrm{C}$ with an even higher $\mathrm{CO}$ partial pressure in the feed stream $(20.0 \mathrm{kPa})$, without using inert gas in the inlet stream, in order to confirm the rigorous methanation effect on identical catalyst, $1 \% \mathrm{Pd} / 20 \% \mathrm{Ni}-20 \% \mathrm{Co}$. The gas product composition from this experiment is presented in Table 3 . The results again showed very high methane production $(2.65 \%)$ together with a decrease in the hydrogen purity until 96 mol \%, which indicates that methanation could become the main problem in the highly efficient SEWGS process for yielding high-purity $\mathrm{H}_{2}$.

As it has been concluded in previous sections, catalyst plays a very important role on the SEWGS reaction. So, catalysts should be rationally designed to have high activity for WGS and methane steam reforming but low methanation activity, besides keeping 
its stability. Ni- and Co-based catalysts are widely accepted as appropriate low-cost metal catalysts for steam reforming of hydrocarbons, since Ni has exhibited good performance by favoring $\mathrm{C}-\mathrm{C}$ and $\mathrm{O}-\mathrm{H}$ bonds rupture and $\mathrm{Co}$ has presented high selectivity to hydrogen in steam reforming reactions [43], but monometallic catalysts could not meet all the requirements. Bi- or multi-metallic catalysts can be the choice to improve the catalyst functionality and Ni-Co bimetallic catalysts could be a good option. A previous kinetic screening study over a series of Ni-Co HT catalysts with different $\mathrm{Ni} / \mathrm{Co}$ ratios has been performed in our research group and it suggested that the lowest methane production keeping high WGS activity was obtained on $30 \% \mathrm{Ni}-10 \% \mathrm{Co}$ HT catalyst [47]. Moreover, noble metals are known to have high reforming and WGS activity and good resistance to coke formation, although the high cost limits their applications. In the present work, Pd has been added in a relative low loading as the third metal to the Ni-Co catalyst. Three catalysts were selected in the present work for the evaluation of effects of the metal composition on SEWGS, namely $1 \% \mathrm{Pd} / 20 \% \mathrm{Ni}$ $20 \%$ Co HT, $20 \% \mathrm{Ni}-20 \% \mathrm{Co}$ and $30 \% \mathrm{Ni}-10 \% \mathrm{Co}$.

The results (Table 3) showed that the methane concentration in the product gas from the SEWGS reaction was much lower on $30 \% \mathrm{Ni}-10 \% \mathrm{Co}$ catalyst as compared to $1 \% \mathrm{Pd} / 20 \% \mathrm{Ni}-20 \% \mathrm{Co}$ catalyst, whereas methanation activity was notably increased on $20 \% \mathrm{Ni}-20 \% \mathrm{Co}$ catalyst. These results showed an improved capacity of the $30 \% \mathrm{Ni}$ $10 \%$ Co catalyst for controlling the methanation reaction during the SEWGS, suggesting its lower methanation activity. Compared to the results obtained on $20 \% \mathrm{Ni}-20 \% \mathrm{Co} \mathrm{HT}$ catalyst, the addition of $\mathrm{Pd}$, i.e. $1 \% \mathrm{Pd} / 20 \% \mathrm{Ni}-20 \% \mathrm{Co} \mathrm{HT}$ catalyst, increased the hydrogen purity and decreased the methane content (Table 3). Our kinetic study of the WGS reaction without sorption enhancement [47] illustrated a slight enhancement of 
the methanation reaction by the Pd promoter in the Ni-Co catalysts. The observation of the decrease in methane concentration and increase in hydrogen concentration during SEWGS on Pd modified catalysts is thus mainly a result of enhanced methane steam reforming activity by $\mathrm{Pd}$ addition. These results again illustrated the importance of the catalysts in the SEWGS reaction and confirmed the necessity of an adequate strategy for a rational design of catalysts.

However, it should be mentioned that the catalyst composition has not been optimized for SEWGS in the present work. Wheeler et al. [38] have indicated a reaction rate order of $\mathrm{Ni}>\mathrm{Ru}>\mathrm{Rh}>\mathrm{Pt}>\mathrm{Pd}$ for high-temperature WGS $\left(300-1000^{\circ} \mathrm{C}\right)$. Panagiotopoulou et al. [53] studied the methanation reaction of $\mathrm{CO}$ over supported noble metal catalysts $(\mathrm{Ru}$, $\mathrm{Rh}, \mathrm{Pt}$ and $\mathrm{Pd}$ ) in the presence and absence of water, showing that the methanation activity of $\mathrm{Rh}$ and $\mathrm{Ru}$ is much higher than one on $\mathrm{Pt}$ and Pd catalysts. However, the selectivity to WGS in the presence of water followed the order $\mathrm{Pt}>\mathrm{Pd}>\mathrm{Rh}>\mathrm{Ru}$ [53]. Jones et al. [54] studied the steam methane reforming on different transition metal catalysis and found an activity order of $\mathrm{Ru} \sim \mathrm{Rh}>\mathrm{Ni} \sim \operatorname{Ir} \sim \mathrm{Pt} \sim \mathrm{Pd}$. Analysis of the reported rate orders points out that $\mathrm{Pt}$ and $\mathrm{Pd}$ are potential promoters for the Ni-Co catalysts to achieve high activity of WGS and steam methane reforming but low activity for the methanation reaction. In addition to $\mathrm{Pd}, \mathrm{Pt}-30 \% \mathrm{Ni}-10 \% \mathrm{Co}$ could be an attractive candidate for SEWGS.

\subsection{Effect of hydrogen addition}

During the sorption-enhanced WGS experiments carried out with high partial pressure of $\mathrm{CO}$, a slow $\mathrm{CO}$ reaction rate at the beginning of the experiment was observed, which resulted in an induction period and a longer time to attain the lowest $\mathrm{CO}$ concentration 
with the maximum production of hydrogen. This phenomenon was more notably observed using $20 \% \mathrm{Ni}-20 \% \mathrm{Co}$ HT catalyst (Fig. 4). In the case of the experiments carried out with low partial pressure of $\mathrm{CO}$, this delay in the $\mathrm{CO}$ consumption was not observed and a very short time was taken to get the maximum conversion, as can be seen in Fig. 3 for the reduced $1 \% \mathrm{Pd} / 20 \% \mathrm{Ni}-20 \% \mathrm{Co}$ HT catalyst. A possible explanation for the initial slow reaction rate is that at the beginning of the experiment with high partial pressures of $\mathrm{CO}$, the catalyst surface is strongly bonded and mostly occupied by carbon monoxide, thus hindering the shift reaction. Once the hydrogen emerges as a result of the WGS reaction, the catalyst surface is also occupied by the product gases including hydrogen and the reaction rate increases.

To confirm this assumption, an additional experiment was conducted in which a small amount of hydrogen was fed in the reactant stream. This experiment was carried out using $20 \% \mathrm{Ni}-20 \% \mathrm{Co}$ HT catalyst, since it was found to be less active at the beginning of the experiment. The reaction conditions were the same as described above but adding $20 \mathrm{~mL} \mathrm{~min}^{-1}$ of $\mathrm{H}_{2}\left(\mathrm{P}_{\mathrm{H} 2}=19.51 \mathrm{kPa}\right)$ in the feed stream. Fig. 4 shows the $\mathrm{CO}$ concentration in the product gas as a function of time on stream after the SEWGS for this experiment compared to the $\mathrm{CO}$ concentrations obtained using the same catalyst without the addition of $\mathrm{H}_{2}$ in the feed stream. The results showed that not only the reaction rate was enhanced by the addition of $\mathrm{H}_{2}$ in the inlet stream, but also complete conversion of $\mathrm{CO}$ was achieved after 20 min on stream. A CO concentration below the detection limit of the Micro GC was not observed in the experiment performed without hydrogen addition. Hence, it could be concluded that a slow reaction rate of $\mathrm{CO}$ at the beginning of the SEWGS experiments with high CO partial pressure can be improved by the addition of a small amount of hydrogen to the reactant stream. In addition, high 
concentration of surface hydrogen on the catalyst is speculated to greatly lower the coking potential $[45,46]$.

\subsection{Highly pure hydrogen production by SEWGS using a novel mixed oxide (CaCeZr) $\mathrm{CO}_{2}$ sorbent and $30 \% \mathrm{Ni}-10 \% \mathrm{Co} \mathrm{HT}$ catalyst}

Since it has been well established in the literature that dolomite loses its $\mathrm{CO}_{2}$ capture capacity over a number of cycles, the stability of the sorbent material can be considered one of the key challenges in the development of the SEWGS technology. Consequently, the choice of an adequate sorbent can be very important to generate a constant stream of pure hydrogen by the SEWGS process. An attempt to address this issue was made in the present work by synthesizing a mixed oxide material to be used as $\mathrm{CO}_{2}$ sorbent, $\mathrm{CaCeZr}$ (10:1:1), whose cyclic stability under relatively high CO partial pressure conditions was tested in the SEWGS process. A sequence of six carbonation/decarbonation cycles in the SEWGS reaction was run. Fig. 5 shows the gas product composition as a function of time on stream after the first cycle of carbonation/decarbonation in the SEWGS process using $\mathrm{CaCeZr}$ as sorbent material. After the first cycle of carbonation/decarbonation, the effluent gas concentration profile showed a stream with highly pure hydrogen $(99.8$ mol \%), $\mathrm{CO}$ concentration of $0.02 \mathrm{~mol} \%$ and $\mathrm{CH}_{4}$ content of $0.16 \mathrm{~mol} \%$.

The results of the successive cycles revealed that the $\mathrm{H}_{2}$ concentration in the gas product remained quite constant over the period of 6 cycles (around $99.8 \mathrm{~mol} \%$ ), methanation reaction was observed to be reduced as the number of cycles proceeded from ca. 0.16 to $0.003 \mathrm{~mol} \%$, whereas the unconverted $\mathrm{CO}$ decreased until $0.01 \mathrm{~mol} \%$. However, the time of the pre-breakthrough stage was reduced as the number of cycles proceeded. Fig. 6 shows the in situ $\mathrm{CO}_{2}$ capture capacity of the calcined $\mathrm{CaCeZr}$ (10:1:1) sorbent 
during six cycles of SEWGS reaction. Despite the good capacity of the mixed oxide sorbent in the initial cycles, its $\mathrm{CO}_{2}$ capture capacity decreased during the first three cycles, but after that it appeared to be stabilized. In contrast, a continued decline in the $\mathrm{CO}_{2}$ capture capacity has been reported for dolomite sorbent. The $\mathrm{CO}_{2}$ capture capacity of $\mathrm{CaCeZr}$ sorbent was found to be $0.378 \mathrm{~g} \mathrm{CO}_{2} / \mathrm{g}$ sorbent during the first cycle, which is comparable, although slightly lower, to that reported in previous works with a similar sorbent by Sultana and Chen [49] under sorption enhanced steam methane reforming at $570{ }^{\circ} \mathrm{C}$ and for ethanol steam reforming at $575^{\circ} \mathrm{C}$. The SEWGS experiments carried out in the present study with dolomite as sorbent material showed that the $\mathrm{CO}_{2}$ capture capacity of dolomite was 0.26 and $0.23 \mathrm{~g} \mathrm{CO}_{2} / \mathrm{g}$ sorbent during the first and second cycles of reaction, respectively. The comparison of the initial capture capacity between the dolomite and the mixed oxide sorbent indicated that the $\mathrm{CaCeZr}(10: 1: 1)$ sorbent had a higher $\mathrm{CO}_{2}$ capture capacity during the first cycle of SEWGS reaction than dolomite under these SEWGS conditions. Since the capture capacity of the dolomite is known to deteriorate during multiple cycle operation, it can be concluded that the $\mathrm{CaCeZr}(10: 1: 1)$ sorbent could show a better stability in sorption enhanced processes.

The reason for the relatively lower $\mathrm{CO}_{2}$ capture capacities under SEWGS reaction conditions as compared to those of sorption enhanced reforming in the previous work [49] could be the difference in reactivity as the two reaction proceed. As indicated above, under the conditions of the present SEWGS reaction study, CO reacts with an initial slow reaction rate, so possibly a lower amount of $\mathrm{CO}_{2}$ is generated in the reaction zone as compared to that produced during the steam methane reforming process. The capture capacity of the sorbent is also a function of the $\mathrm{CO}_{2}$ partial pressure and hence highly depends on the amount of $\mathrm{CO}_{2}$ generated in the reaction zone. A slow initial 
production of $\mathrm{CO}_{2}$ could result in a low capture capacity under the SEWGS conditions investigated as compared to the reforming process. Finally, it can be deduced that the use of the CaCeZr mixed oxide sorbent together with an appropriate WGS catalyst could for the first time allow stable production of highly pure hydrogen, in particular fuel-cell grade hydrogen, at low CO pressures by cyclic SEWGS process.

In order to understand the mechanism of the observed deactivation of sorbents, the characterization of both fresh and spent catalyst $(10 \% \mathrm{Co}-30 \% \mathrm{Ni})$ and sorbent material (CaCeZr 10:1:1) were performed by means of XRD and BET surface area measurements. The XRD spectra of the fresh calcined sorbent is shown in Fig. 7. The XRD pattern indicates the presence of $\mathrm{CaO}$ and $\mathrm{Ce}_{0.5} \mathrm{Zr}_{0.5} \mathrm{O}_{2}$ phases in a well-crystalline structure of the sorbent material. The BET surface area of the calcined sorbent was found to be $31.2 \mathrm{~m}^{2} \mathrm{~g}^{-1}$ and pore volume of $0.14 \mathrm{~cm}^{3} \mathrm{~g}^{-1}$ (Table 4).

The XRD analysis of the fresh $10 \%$ Co- $30 \%$ Ni HT catalyst (Fig. 8) shows prominent $2 \theta$ peaks at about $11.5,23.1,34.9,39.3,46.8$ and $62.1^{\circ}$, characteristic for hydrotalcites [43], i.e. with the general pattern of sharp, symmetric and intense lines at low values of $2 \theta$ angle and relatively less intense and asymmetric lines at higher angular values. The XRD spectra of the calcined catalyst sample (Fig. 9) shows that there is no residual hydrotalcite structure due to the loss of water and carbon dioxide from the anionic interlayer of hydrotalcite precursors and the presence of poorly crystallized mixed oxide phases. The peaks in the XRD pattern correspond to the possible presence of $\mathrm{NiO}$, $\mathrm{Co}_{3} \mathrm{O}_{4}, \mathrm{CoAl}_{2} \mathrm{O}_{4}, \mathrm{NiCo}_{2} \mathrm{O}_{4}, \mathrm{MgAl}_{2} \mathrm{O}_{4}$ and $\mathrm{MgNiO}_{2}$ phases, which are however impossible to be distinguished due to heavy overlaps. The BET surface area and pore volume of the calcined catalyst were found to be $175 \mathrm{~m}^{2} \mathrm{~g}^{-1}$ and of $0.6 \mathrm{~cm}^{3} \mathrm{~g}^{-1}$, respectively (Table 4). 
After completion of seven cycles of SEWGS, it was difficult to separate the catalyst and the sorbent from the catalyst/sorbent mixture. Therefore, the XRD and BET analyses of the sorbent/catalyst $(20 / 1 \mathrm{~g} / \mathrm{g})$ mixture were done in order to evaluate the changes in the physical-chemical properties. The XRD pattern is shown in Fig. 10, which indicates the presence of $\mathrm{CaO}, \mathrm{Ce}_{0.5} \mathrm{Zr}_{0.5} \mathrm{O}_{2}$ and $\mathrm{CaZrO}_{3}$ from the sorbent, whereas Ni-containing oxides (NiO, $\mathrm{MgO}$ and $\mathrm{Ni}-\mathrm{Mg}$ oxides) are identified from the catalyst. The catalyst did not transfer back to hydrotalcite structure during the cycles. The average crystal sizes have been estimated from the XRD peaks using Scherrer equation, which are summarized in Table 4. The results show a slight increase in $\mathrm{CaO}$ crystal of sorbent from $40 \mathrm{~nm}$ to $49 \mathrm{~nm}$ after seven cycles. Similarly, the average crystallite size of $\mathrm{Ce}_{0.5} \mathrm{Zr}_{0.5} \mathrm{O}_{2}$ increased from $10 \mathrm{~nm}$ to $16 \mathrm{~nm}$. The new phase $\mathrm{CaZrO}_{3}$ formed showed a crystal size of $32 \mathrm{~nm}$. In the case of the catalyst, XRD results showed a strong growth in the Ni-containing oxides crystal from $3.8 \mathrm{~nm}$ to $24 \mathrm{~nm}$ after seven cycles. The crystal size of Ni-containing oxides has been estimated by considering the XRD peak at $2 \theta$ value of ca. $44^{\circ}$.

The initial average surface area of the catalyst/sorbent mixture was calculated to be 38 $\mathrm{m}^{2} \mathrm{~g}^{-1}$, whereas it was reduced to $12 \mathrm{~m}^{2} \mathrm{~g}^{-1}$ after seven cycles (Table 4). Similarly the pore volume of the mixture was reduced from $0.16 \mathrm{~cm}^{3} \mathrm{~g}^{-1}$ to $0.05 \mathrm{~cm}^{3} \mathrm{~g}^{-1}$ after seven cycles of SEWGS. Obviously, the surface area of catalysts and sorbents significantly decreased after cycles. We previously reported [55] that the surface area of hydrotalcitederived supports decreased from about $200 \mathrm{~m}^{2} \mathrm{~g}^{-1}$ to $20-30 \mathrm{~m}^{2} \mathrm{~g}^{-1}$ after more than 50 hours under steam reforming reaction at $630{ }^{\circ} \mathrm{C}$ and 20 bars, whereas Ni particles were relatively stable and $\mathrm{Ni}$ dispersion decreased about $20 \%$. In addition, regeneration of the sorbents at high temperature could also cause sintering of catalysts and sorbents, 
resulting in an irreversible deactivation. It should be mentioned that the Ni-Co catalysts were calcined at a relatively low temperature $\left(600^{\circ} \mathrm{C}\right)$ in the present work, which was optimized to get a high Ni dispersion but not optimized for the SEWGS reaction, where a high temperature $\left(750^{\circ} \mathrm{C}\right)$ is required for the regeneration of the sorbents. This fact recommends a high temperature $\left(>750^{\circ} \mathrm{C}\right)$ for calcination of catalysts in future works.

The surface area of the sorbents must have been also reduced by cycling operation of SEWGS, since the crystal size of $\mathrm{CaO}$ and $\mathrm{Ce}_{0.5} \mathrm{Zr}_{0.5} \mathrm{O}_{2}$ increased, and a new phase of $\mathrm{CaZrO}_{3}$ with a relatively large crystal size was formed. It has been also demonstrated in the literature that the presence of steam could have deactivated the Ca-containing mixed oxide sorbents during cycles due to sintering [56,57]. Taking into account the stable $\mathrm{H}_{2}$, $\mathrm{CH}_{4}$ and $\mathrm{CO}$ contents during the SEWGS cycles, the observed decrease in the $\mathrm{CO}_{2}$ capacity (Fig. 5) will be mainly result of the deactivation of the sorbent due to the BET surface area decrease, the $\mathrm{CaO}$ sintering and the loss of $\mathrm{CaO}$ active material by formation of $\mathrm{CaZrO}_{3}$.

\section{Conclusions}

The integration of in-situ $\mathrm{CO}_{2}$ capture to the water gas shift reaction, i.e. sorptionenhanced water gas shift (SEWGS) process, have been investigated to effectively produce a highly hydrogen-rich gas stream in a single step. The experimental results and the thermodynamic analysis showed that incorporating in-situ $\mathrm{CO}_{2}$ capture into the water gas shift reaction is essential to achieve a one-step high yield of hydrogen. The SEWGS reaction for hydrogen production was studied in a fixed-bed reactor using $1 \% \mathrm{Pd} / 20 \% \mathrm{Ni}-20 \% \mathrm{Co} \mathrm{HT}$ catalyst and calcined dolomite as $\mathrm{CO}_{2}$ sorbent. Ni-Co catalysts and a novel $\mathrm{CaCeZr}$ mixed oxide as sorbent were also studied. We clearly 
illustrated that the catalyst plays a significant role in the one-step hydrogen production by SEWGS. The $1 \% \mathrm{Pd} / 20 \% \mathrm{Ni}-20 \% \mathrm{Co} \mathrm{HT}$ catalyst was found to be the most active for attaining the complete $\mathrm{CO}$ conversion, but it was associated with significant methanation when low temperatures and high $\mathrm{CO}$ partial pressures in the feed stream were used, which was also detected with the use of $20 \% \mathrm{Ni}-20 \% \mathrm{Co}$ HT catalyst. The results indicated that methanation reaction increased strongly with increasing $\mathrm{CO}$ partial pressure in the feed stream. The utilization of $30 \% \mathrm{Ni}-10 \% \mathrm{Co}$ HT catalyst was proved to be the best option for the studied SEWGS process due to the reduced methanation reaction at low temperatures using high $\mathrm{CO}$ partial pressures in the feed stream. Furthermore, the synthesized $\mathrm{CaO}$-based mixed oxide, $\mathrm{CaCeZr}$, sorbent could be a good option for using in SEWGS reaction due to its stability and capture capacity.

There is an optimized temperature for hydrogen production by the SEWGS reaction. The hydrogen production by SEWGS is kinetically limited by the WGS reaction at low temperatures $\left(425-475^{\circ} \mathrm{C}\right)$, while it is thermodynamically unfavorable at high temperatures $\left(475-550{ }^{\circ} \mathrm{C}\right)$. The concentration of hydrogen from SEWGS reaction was higher than $99.8 \mathrm{~mol} \%$ between $450-525^{\circ} \mathrm{C}$, steam/CO ratio of 4 and $\mathrm{CO}$ partial pressure of $12.5 \mathrm{kPa}$ using $1 \% \mathrm{Pd} / 20 \% \mathrm{Ni}-20 \% \mathrm{Co} \mathrm{HT}$ catalyst and dolomite as sorbent. The lowest $\mathrm{CO}$ concentration was found at temperatures of $475-500{ }^{\circ} \mathrm{C}$, whereas the methanation reaction was effectively reduced at temperatures higher than $500{ }^{\circ} \mathrm{C}$. Under the conditions of the present study, a maximum hydrogen concentration of $99.93 \%$ together with a very low $\mathrm{CH}_{4}$ concentration $(0.01 \mathrm{~mol} \%)$ and negligible $\mathrm{CO}$ content (below the detectable limit of the Micro GC analyzer) was obtained after the SEWGS reaction at $500{ }^{\circ} \mathrm{C}$, steam/CO of 4 and $\mathrm{CO}$ partial pressure of $12.5 \mathrm{kPa}$. Such a low level of CO might allow the direct use of the gas product in low-temperature proton exchange 
membrane (PEM) fuel cells without subsequent CO removal. Under these conditions, the reduction of the $1 \% \mathrm{Pd} / 20 \% \mathrm{Ni}-20 \% \mathrm{Co}$ HT catalyst between successive SEWGS cyclic reactions was proved to be necessary in order to reach full $\mathrm{CO}$ conversion. On the other hand, the slow reaction rate found in the preliminary stage of reaction with high partial pressure of $\mathrm{CO}$ in the feed stream can be overcome by the addition of hydrogen in the inlet stream, which not only significantly enhanced the rate of shift reaction but also resulted in the complete conversion of $\mathrm{CO}$.

The major potential advantages of the studied process are the production of a highpurity hydrogen stream from water gas shift reaction in a single step and the possibility of obtaining a fuel-cell grade hydrogen gas with a low enough $\mathrm{CO}$ concentration. However, future works studying the activity and stability of the catalysts over an increased number of cycles under high $\mathrm{CO}$ and steam partial pressure conditions would be still necessary. Also, the addition of Pd to the $30 \% \mathrm{Ni}-10 \% \mathrm{Co}$ HT catalyst should be tested, since it could potentially incorporate significant advantages in relation to the improvement in the $\mathrm{CO}$ conversion and reduction of methanation reaction during the SEWGS process.

\section{Acknowledgements}

T. Noor would like to acknowledge Research Council of Norway for financial support under its KOSK project 10305300. M.V. Gil acknowledges funding from the CSIC JAE-Doc program, Spain, co-financed by the European Social Fund, and support from the Research Council of Norway under the Yggdrasil programme. 


\section{References}

[1] R. Gupta, K. Pant, Hydrogen Fuel - Production, Transport, and Storage, CRC Press Taylor \& Francis Group, 2009.

[2] J.D. Holladay, J. Hu, D.L. King, Y. Wang, Catal. Today 139 (2009) 244-260.

[3] T. Chapman, Physics World, 2002.

[4] C. Ratnasamy, J.P. Wagner, Cat. Rev. - Sci. Eng. 51 (2009) 325-440.

[5] C. Rhodes, B. Peter Williams, F. King, G.J. Hutchings, Catal. Commun. 3 (2002) 381-384.

[6] M.V. Twigg, Catalyst handbook, 2nd ed., Manson Publishing, London, 1996.

[7] A.F. Ghenciu, Curr. Opin. Solid State Mater. Sci. 6 (2002) 389-399.

[8] T.V. Choudhary, D.W. Goodman, Catal. Today 77 (2002) 65-78.

[9] H.-J. Ryu, S.-H. Jo, Y.C. Park, C.-K. Yi, Reaction characteristics of two water gas shift catalysts in a bubbling fluidized bed reactor for SEWGS process, The 13th International Conference on Fluidization - New Paradigm in Fluidization Engineering, 2010.

[10] N.A. Koryabkina, A.A. Phatak, W.F. Ruettinger, R.J. Farrauto, F.H. Ribeiro, J. Catal. 217 (2003) 233-239.

[11] D.P. Harrison, Ind. Eng. Chem. Res. 47 (2008) 6486-6501.

[12] L. Barelli, G. Bidini, F. Gallorini, S. Servili, Energy 33 (2008) 554-570.

[13] D. Chen, L. He, ChemCatChem 3 (2011) 490-511.

[14] C.R. Müller, R. Pacciani, C.D. Bohn, S.A. Scott, J.S. Dennis, Ind. Eng. Chem. Res. 48 (2009) 10284-10291.

[15] R.W. Stevens Jr, A. Shamsi, S. Carpenter, R. Siriwardane, Fuel 89 (2010) 12801286.

[16] P.D. Cobden, P. van Beurden, H.T.J. Reijers, G.D. Elzinga, S.C.A. Kluiters, J.W. Dijkstra, D. Jansen, R.W. van den Brink, Int. J. Greenh. Gas Control 1 (2007) 170-179.

[17] Z. Yong, V. Mata, A.r.E. Rodrigues, Sep. Purif. Technol. 26 (2002) 195-205.

[18] H.M. Jang, K.B. Lee, H.S. Caram, S. Sircar, Chem. Eng. Sci. 73 (2012) 431-438.

[19] M.G. Beaver, H.S. Caram, S. Sircar, Int. J. Hydrogen Energy 34 (2009) 29722978.

[20] E. Ochoa-Fernández, C. Lacalle-Vilà, T. Zhao, M. Rønning, D. Chen, in: M.S. Fábio Bellot Noronha, S.-A. Eduardo Falabella (Eds.), Stud. Surf. Sci. Catal., Elsevier, 2007, pp. 159-164.

[21] W. Gluud, K. Keller, R. Schonfelder, W. Klempt, Production of Hydrogen, U.S. Patent 1816523, 1931.

[22] C. Han, D.P. Harrison, Chem. Eng. Sci. 49 (1994) 5875-5883.

[23] L. He, D. Chen, ChemSusChem 3 (2010) 1169-1171.

[24] S. Ramkumar, L.-S. Fan, Energy Fuels 24 (2010) 4408-4418.

[25] G. Wu, C. Zhang, S. Li, Z. Huang, S. Yan, S. Wang, X. Ma, J. Gong, Energy Environ. Sci. 5 (2012) 8942-8949.

[26] B. Dou, G.L. Rickett, V. Dupont, P.T. Williams, H. Chen, Y. Ding, M. Ghadiri, Bioresour. Technol. 101 (2010) 2436-2442.

[27] K. Johnsen, J.R. Grace, S.S.E.H. Elnashaie, L. Kolbeinsen, D. Eriksen, Industrial \& Engineering Chemistry Research 45 (2006) 4133-4144.

[28] A. Silaban, M. Narcida, D.P. Harrison, Chem. Eng. Commun. 146 (1996) 149162. 
[29] M. Kato, S. Yoshikawa, K. Nakagawa, J. Mater. Sci. Lett. 21 (2002) 485-487.

[30] M.A. Escobedo Bretado, M.D. Delgado Vigil, J.S. Gutiérrez, A. López Ortiz, V. Collins-Martínez, Int. J. Hydrogen Energy 35 (2010) 12083-12090.

[31] M.A. Escobedo Bretado, M.D. Delgado Vigil, V.H. Collins-Martinez, A. López Ortiz, Int. J. Chem. React. Eng. 6 (2008) 1542-6580.

[32] N.H. Florin, J. Blamey, P.S. Fennell, Energy \& Fuels 24 (2010) 4598-4604.

[33] J. Mastin, A. Aranda, J. Meyer, Energy Procedia 4 (2011) 1184-1191.

[34] H.A.J. van Dijk, S. Walspurger, P.D. Cobden, D. Jansen, R.W. van den Brink, F.G. de Vos, Energy Procedia 1 (2009) 639-646.

[35] S.S. Hla, D. Park, G.J. Duffy, J.H. Edwards, D.G. Roberts, A. Ilyushechkin, L.D. Morpeth, T. Nguyen, Chem. Eng. J. 146 (2009) 148-154.

[36] S. Natesakhawat, X. Wang, L. Zhang, U.S. Ozkan, J. Mol. Catal. A: Chem. 260 (2006) 82-94.

[37] J.Y. Lee, D.-W. Lee, K.-Y. Lee, Y. Wang, Catal. Today 146 (2009) 260-264.

[38] C. Wheeler, A. Jhalani, E.J. Klein, S. Tummala, L.D. Schmidt, J. Catal. 223 (2004) 191-199.

[39] S. Hilaire, X. Wang, T. Luo, R.J. Gorte, J. Wagner, Appl. Catal. A-Gen 215 (2001) 271-278.

[40] K.-R. Hwang, C.-B. Lee, J.-S. Park, J. Power Sources 196 (2011) 1349-1352.

[41] Y. Schuurman, C. Marquez-Alvarez, V.C.H. Kroll, C. Mirodatos, Catal. Today 46 (1998) 185-192.

[42] J. Fermoso, F. Rubiera, D. Chen, Energy Environ. Sci. 5 (2012) 6358-6367.

[43] L. He, H. Berntsen, E. Ochoa-Fernández, J. Walmsley, E. Blekkan, D. Chen, Top. Catal. 52 (2009) 206-217.

[44] X. Hu, G. Lu, Appl. Catal. B-Environ. 88 (2009) 376-385.

[45] L. He, H. Berntsen, D. Chen, J. Phys. Chem. A 114 (2010) 3834-3844.

[46] L. He, J.M.S. Parra, E.A. Blekkan, D. Chen, Energy Environ. Sci. 3 (2010) 10461056.

[47] T. Noor, J. Zhu, J. Yang, D. Chen, (in preparation).

[48] E. Ochoa-Fernández, C. Lacalle-Vilà, K. Christensen, J. Walmsley, M. Rønning, A. Holmen, D. Chen, Top. Catal. 45 (2007) 3-8.

[49] K.S. Sultana, D. Chen, Catal. Today 171 (2011) 43-51.

[50] L. He, D. Chen, ChemSusChem 5 (2012) 587-595.

[51] J. Fermoso, L. He, D. Chen, Int. J. Hydrogen Energy 37 (2012) 14047-14054.

[52] E. Ochoa-Fernandez, M. Ronning, X. Yu, T. Grande, D. Chen, Industrial \& Engineering Chemistry Research 47 (2008) 434-442.

[53] P. Panagiotopoulou, D.I. Kondarides, X.E. Verykios, Applied Catalysis A: General 344 (2008) 45-54.

[54] G. Jones, J.G. Jakobsen, S.S. Shim, J. Kleis, M.P. Andersson, J. Rossmeisl, F. Abild-Pedersen, T. Bligaard, S. Helveg, B. Hinnemann, J.R. Rostrup-Nielsen, I. Chorkendorff, J. Sehested, J.K. Nørskov, J. Catal. 259 (2008) 147-160.

[55] K.O. Christensen, D. Chen, R. Lødeng, A. Holmen, Applied Catalysis A: General 314 (2006) 9-22.

[56] R.H. Borgwardt, Chem. Eng. Sci. 44 (1989) 53-60.

[57] R.H. Borgwardt, Ind. Eng. Chem. Res. 28 (1989) 493-500. 


\section{Figure captions}

Fig. 1. Schematic flow diagram of the experimental setup used for SEWGS experiments.

Fig. 2. Evolution of the product gas composition (dry basis; $\bullet \mathrm{H}_{2} ; \bullet \mathrm{CO} ;-\mathrm{CH}_{4}$; $\Delta \mathrm{CO}_{2}$ ) with time on stream during the SEWGS reaction. Reaction conditions: $425^{\circ} \mathrm{C}$, $1 \mathrm{~atm}$, steam $/ \mathrm{CO}=4 \mathrm{~mol} / \mathrm{mol}$, sorbent $/$ catalyst $=25 \mathrm{~g} / \mathrm{g}, \mathrm{CO}$ partial pressure in the feed stream $=6.25 \mathrm{kPa}, \mathrm{H}_{2} \mathrm{O}$ partial pressure in the feed stream $=25.00 \mathrm{kPa}, \mathrm{WHSV}=3.44 \mathrm{~h}^{-1}$, calcined dolomite as sorbent and $1 \% \mathrm{Pd} / 20 \% \mathrm{Ni}-20 \% \mathrm{Co}$ HT catalyst.

Fig. 3. Evolution of the product gas composition with time on stream during the SEWGS reaction using reduced and unreduced $1 \% \mathrm{Pd} / 20 \% \mathrm{Ni}-20 \% \mathrm{Co}$ HT catalyst (dry basis; • $\mathrm{H}_{2}$-red; $\bullet \mathrm{CO}$-red; $-\mathrm{CH}_{4}$-red; $\triangle \mathrm{CO}_{2}$-red; $\diamond \mathrm{H}_{2}$-unred; ○ CO-unred; $\square \mathrm{CH}_{4}{ }^{-}$ unred; $\Delta \mathrm{CO}_{2}$-unred). Reaction conditions: $425^{\circ} \mathrm{C}, 1 \mathrm{~atm}$, steam $/ \mathrm{CO}=4 \mathrm{~mol} / \mathrm{mol}$, WHSV $=3.44 \mathrm{~h}^{-1}, \quad$ sorbent/catalyst $=25 \mathrm{~g} / \mathrm{g}, \quad \mathrm{CO}$ partial pressure in the feed stream $=6.25 \mathrm{kPa}, \mathrm{H}_{2} \mathrm{O}$ partial pressure in the feed stream $=25.00 \mathrm{kPa}$ and calcined dolomite as sorbent.

Fig. 4. Evolution of the $\mathrm{CO}$ concentration in the product gas with time on stream during the SEWGS reaction using catalysts with different metal composition (dry basis; $1 \% \mathrm{Pd} / 20 \% \mathrm{Ni}-20 \% \mathrm{Co}$ HT and $\mathrm{P}_{\mathrm{CO}}=15.15 \mathrm{kPa}, \mathrm{P}_{\mathrm{H} 2 \mathrm{O}}=60.61 \mathrm{kPa} ; \circ 20 \% \mathrm{Ni}-20 \% \mathrm{Co} \mathrm{HT}$ and $\mathrm{P}_{\mathrm{CO}}=15.15 \mathrm{kPa}, \quad \mathrm{P}_{\mathrm{H} 2 \mathrm{O}}=60.61 \mathrm{kPa} ; \quad \cdot 30 \% \mathrm{Ni}-10 \% \mathrm{Co} \quad \mathrm{HT}$ and $\mathrm{P}_{\mathrm{CO}}=15.15 \mathrm{kPa}$, $\mathrm{P}_{\mathrm{H} 2 \mathrm{O}}=60.61 \mathrm{kPa} ; \quad-20 \% \mathrm{Ni}-20 \% \mathrm{Co} \quad \mathrm{HT} \quad$ and $\quad \mathrm{P}_{\mathrm{CO}}=12.20 \mathrm{kPa}, \quad \mathrm{P}_{\mathrm{H} 2 \mathrm{O}}=48.78 \mathrm{kPa}$, $\left.\mathrm{P}_{\mathrm{H} 2}=19.51 \mathrm{kPa}\right)$. Reaction conditions: $450^{\circ} \mathrm{C}, \quad 1 \mathrm{~atm}, \quad$ steam $/ \mathrm{CO}=4 \mathrm{~mol} / \mathrm{mol}$, WHSV $=2.87 \mathrm{~h}^{-1}$, sorbent $/$ catalyst $=15 \mathrm{~g} / \mathrm{g}$ and calcined dolomite as sorbent. 
Fig. 5. Evolution of the product gas composition with time on stream during the first cycle of carbonation/decarbonation in the SEWGS process using CaCeZr (10:1:1) as sorbent (dry basis; $\bullet \mathrm{H}_{2} ; \bullet \mathrm{CO} ; \boldsymbol{\sim} \mathrm{CH}_{4} ; \boldsymbol{\Delta} \mathrm{CO}_{2}$ ). Reaction conditions: $450{ }^{\circ} \mathrm{C}, 1 \mathrm{~atm}$, steam $/ \mathrm{CO}=4 \mathrm{~mol} / \mathrm{mol}, \mathrm{WHSV}=2.29 \mathrm{~h}^{-1}$, sorbent $/$ catalyst $=20 \mathrm{~g} / \mathrm{g}, \mathrm{CO}$ partial pressure in the feed stream $=14.29 \mathrm{kPa}, \mathrm{H}_{2} \mathrm{O}$ partial pressure in the feed stream $=57.14 \mathrm{kPa}$ and $30 \% \mathrm{Ni}-10 \% \mathrm{Co}$ HT catalyst.

Fig. 6. In situ $\mathrm{CO}_{2}$ capture capacity of calcined $\mathrm{CaCeZr}(10: 1: 1)$ sorbent during the first six cycles of SEWGS reaction. Reaction conditions: $450{ }^{\circ} \mathrm{C}, 1 \mathrm{~atm}$, steam $/ \mathrm{CO}=4 \mathrm{~mol} / \mathrm{mol}, \mathrm{WHSV}=2.29 \mathrm{~h}^{-1}$ sorbent $/$ catalyst $=20 \mathrm{~g} / \mathrm{g}, \mathrm{CO}$ partial pressure in the feed stream $=14.29 \mathrm{kPa}, \mathrm{H}_{2} \mathrm{O}$ partial pressure in the feed stream $=57.14 \mathrm{kPa}$ and $30 \% \mathrm{Ni}-10 \% \mathrm{Co}$ HT catalyst.

Fig. 7. XRD pattern of calcined $\mathrm{Ca}: \mathrm{Ce}: \mathrm{Zr}(10: 1: 1)$ mix oxide sorbent, $\mathrm{CaO}(\bullet)$, $\mathrm{Ce}_{0.5} \mathrm{Zr}_{0.5} \mathrm{O}_{2}(\bullet)$.

Fig. 8. XRD pattern of uncalcined $30 \% \mathrm{Ni}-10 \% \mathrm{Co}$ hydrotalcite catalyst.

Fig. 9. XRD pattern of calcined $30 \% \mathrm{Ni}-10 \% \mathrm{Co}$ hydrotalcite catalyst. Peaks marked with $(\diamond)$ are characteristic of $\mathrm{NiO}, \mathrm{MgO}, \mathrm{MgNiO}_{2}, \mathrm{Co}_{3} \mathrm{O}_{4}, \mathrm{CoAl}_{2} \mathrm{O}_{4}, \mathrm{NiAl}_{2} \mathrm{O}_{4}, \mathrm{MgCo}_{2} \mathrm{O}_{4}$ and $\mathrm{Al}_{2} \mathrm{MgO}_{4}$.

Fig. 10. XRD pattern of CaCeZr (10:1:1) and 30\%Ni-10\%Co hydrotalcite catalyst after seven cycles of SEWGS. $\mathrm{CaO}(\bullet), \mathrm{Ce}_{0.5} \mathrm{Zr}_{0.5} \mathrm{O}_{2}(\bullet) \mathrm{CaZrO}_{3}(\Delta) \mathrm{NiO}(0)$. 


\section{Table 1}

Effect of temperature on product gas composition from SEWGS reaction. Reaction conditions: steam $/ \mathrm{CO}=4 \mathrm{~mol} / \mathrm{mol}, 1 \mathrm{~atm}, \mathrm{WHSV}=6.88 \mathrm{~h}^{-1}\left(\mathrm{P}_{\mathrm{CO}}=12.50 \mathrm{kPa}\right)$ and $3.44 \mathrm{~h}^{-1}$ $\left(\mathrm{P}_{\mathrm{CO}}=6.25 \mathrm{kPa}\right)$, sorbent $/$ catalyst $=10 \mathrm{~g} / \mathrm{g}$, calcined dolomite as sorbent and $1 \% \mathrm{Pd} / 20 \% \mathrm{Ni}-20 \% \mathrm{Co}$ HT catalyst.

\begin{tabular}{|c|c|c|c|c|}
\hline \multirow[t]{2}{*}{ Temperature $\left[{ }^{\circ} \mathrm{C}\right]$} & \multicolumn{4}{|c|}{ Dry product gas composition [mol \%] } \\
\hline & $\mathrm{H}_{2}$ & $\mathrm{CH}_{4}$ & $\mathrm{CO}$ & $\mathrm{CO}_{2}$ \\
\hline \multicolumn{5}{|c|}{ SEWGS experiments with $\mathrm{P}_{\mathrm{CO}}=12.50 \mathrm{kPa}$ and $\mathrm{P}_{\mathrm{H} 2 \mathrm{O}}=50.00 \mathrm{kPa}$} \\
\hline 425 & 99.05 & 0.91 & 0.04 & 0.004 \\
\hline 450 & 99.84 & 0.15 & 0.004 & 0.004 \\
\hline 475 & 99.77 & 0.23 & n.d. ${ }^{\mathrm{a}}$ & 0.004 \\
\hline 500 & 99.93 & 0.01 & n.d. ${ }^{\mathrm{a}}$ & 0.06 \\
\hline 525 & 99.84 & 0.05 & 0.04 & 0.07 \\
\hline 550 & 99.63 & 0.01 & 0.04 & 0.31 \\
\hline \multicolumn{5}{|l|}{ Equilibrium } \\
\hline 425 & 99.98 & 0.011 & 0.0001 & 0.004 \\
\hline 450 & 99.98 & 0.011 & 0.0005 & 0.011 \\
\hline 475 & 99.96 & 0.011 & 0.002 & 0.030 \\
\hline 500 & 99.91 & 0.010 & 0.005 & 0.075 \\
\hline 525 & 99.80 & 0.010 & 0.014 & 0.177 \\
\hline 550 & 99.56 & 0.009 & 0.036 & 0.397 \\
\hline \multicolumn{5}{|c|}{ SEWGS experiments with $\mathrm{P}_{\mathrm{CO}}=6.25 \mathrm{kPa}$ and $\mathrm{P}_{\mathrm{H} 2 \mathrm{O}}=25.00 \mathrm{kPa}$} \\
\hline 425 & 98.64 & 1.34 & n.d. ${ }^{a}$ & 0.01 \\
\hline 450 & 99.35 & 0.63 & n.d. ${ }^{a}$ & 0.02 \\
\hline \multicolumn{5}{|l|}{ Equilibrium } \\
\hline 425 & 99.98 & 0.011 & 0.0001 & 0.004 \\
\hline 450 & 99.98 & 0.011 & 0.0005 & 0.011 \\
\hline
\end{tabular}

${ }^{\mathrm{a}}$ n.d.: not detected. 


\section{Table 2}

Effect of steam/CO ratio and $\mathrm{CO}$ partial pressure in the feed stream on product gas composition from SEWGS reaction. Reaction conditions: $425^{\circ} \mathrm{C}$; $1 \mathrm{~atm}$, WHSV $=3.44 \mathrm{~h}^{-1}, \quad$ sorbent $/$ catalyst $=10 \mathrm{~g} / \mathrm{g}, \quad$ calcined dolomite as sorbent and $1 \% \mathrm{Pd} / 20 \% \mathrm{Ni}-20 \%$ Co HT catalyst.

\begin{tabular}{|c|c|c|c|c|c|}
\hline \multirow[t]{2}{*}{ Steam/CO } & \multirow[t]{2}{*}{$\mathrm{P}_{\mathrm{CO}}\left(\mathrm{P}_{\mathrm{H} 2 \mathrm{O}}\right)[\mathrm{kPa}]$} & \multicolumn{4}{|c|}{ Dry product gas composition [mol \%] } \\
\hline & & $\mathrm{H}_{2}$ & $\mathrm{CH}_{4}$ & $\mathrm{CO}$ & $\mathrm{CO}_{2}$ \\
\hline \multicolumn{6}{|c|}{ SEWGS experiments } \\
\hline \multirow{2}{*}{4} & $6.25(25.00)$ & 98.64 & 1.34 & n.d. ${ }^{\mathrm{a}}$ & 0.01 \\
\hline & $15.15(60.61)$ & 96.06 & 3.17 & 0.75 & 0.01 \\
\hline \multirow{2}{*}{3} & $6.25(18.75)$ & 99.26 & 0.70 & n.d. ${ }^{a}$ & 0.02 \\
\hline & $17.86(53.57)$ & 95.17 & 4.37 & 0.43 & 0.01 \\
\hline \multirow{2}{*}{2} & $6.25(12.50)$ & 98.91 & 1.05 & 0.01 & 0.01 \\
\hline & $21.74(43.48)$ & 89.57 & 10.24 & 0.13 & 0.04 \\
\hline \multicolumn{6}{|l|}{ Equilibrium } \\
\hline \multirow{2}{*}{4} & $6.25(25.00)$ & 99.98 & 0.011 & 0.0001 & 0.004 \\
\hline & $15.15(60.61)$ & 99.98 & 0.011 & 0.0001 & 0.004 \\
\hline \multirow{2}{*}{3} & $6.25(18.75)$ & 99.96 & 0.034 & 0.0002 & 0.003 \\
\hline & $17.86(53.57)$ & 99.96 & 0.034 & 0.0002 & 0.003 \\
\hline \multirow{2}{*}{2} & $6.25(12.50)$ & 99.80 & 0.197 & 0.0002 & 0.002 \\
\hline & $21.74(43.48)$ & 99.80 & 0.197 & 0.0002 & 0.002 \\
\hline
\end{tabular}

${ }^{\mathrm{a}}$ n.d.: not detected. 


\section{Table 3}

Effect of metal composition in the catalyst on product gas composition from SEWGS reaction. Reaction conditions: $450{ }^{\circ} \mathrm{C} ; 1 \mathrm{~atm}$, steam $/ \mathrm{CO}=4 \mathrm{~mol} / \mathrm{mol}$, WHSV $=6.88 \mathrm{~h}^{-1}$ $\left(\mathrm{P}_{\mathrm{CO}}=20.00 \mathrm{kPa}\right)$ and $2.87 \mathrm{~h}^{-1}\left(\mathrm{P}_{\mathrm{CO}}=15.15 \mathrm{kPa}\right)$, sorbent/catalyst $=15 \mathrm{~g} / \mathrm{g}$ and calcined dolomite as sorbent.

\begin{tabular}{llllll}
\hline Catalyst & $\mathrm{P}_{\mathrm{CO}}\left(\mathrm{P}_{\mathrm{H} 2 \mathrm{O}}\right)[\mathrm{kPa}]$ & \multicolumn{4}{c}{ Dry product gas composition [mol \%] } \\
& & $\mathrm{H}_{2}$ & $\mathrm{CH}_{4}$ & $\mathrm{CO}$ & $\mathrm{CO}_{2}$ \\
\hline SEWGS experiments & & & & & \\
$1 \% \mathrm{Pd} / 20 \% \mathrm{Ni}-20 \% \mathrm{Co} \mathrm{HT}$ & $20.00(80.00)$ & 95.73 & 2.65 & 1.61 & 0.02 \\
$1 \% \mathrm{Pd} / 20 \% \mathrm{Ni}-20 \% \mathrm{Co} \mathrm{HT}$ & $15.15(60.61)$ & 99.17 & 0.78 & 0.02 & 0.03 \\
$20 \% \mathrm{Ni}-20 \% \mathrm{Co} \mathrm{HT}$ & $15.15(60.61)$ & 98,27 & 2.13 & 0.03 & 0.03 \\
$30 \% \mathrm{Ni}-10 \% \mathrm{Co} \mathrm{HT}$ & $15.15(60.61)$ & 99.74 & 0.20 & 0.03 & 0.03 \\
\hline Equilibrium & & 99.98 & 0.011 & 0.0005 & 0.011 \\
\hline
\end{tabular}




\section{Table 4}

Physical-chemical properties of catalyst $(10 \% \mathrm{Co}-30 \% \mathrm{Ni} \mathrm{HT})$ and sorbent $(\mathrm{CaCeZr})$ before and after SEWGS experiments.

\begin{tabular}{|c|c|c|c|c|}
\hline \multirow[t]{2}{*}{ Sample } & \multirow{2}{*}{$\frac{\text { XRD analysis }}{\text { Crystallite Size (nm) }}$} & \multicolumn{3}{|l|}{$\mathrm{N}_{2}$ Sorption } \\
\hline & & $\begin{array}{l}\text { BET surface } \\
\text { area }\left(\mathrm{m}^{2} \mathrm{~g}^{-1}\right)\end{array}$ & $\begin{array}{l}\text { Pore volume } \\
\left(\mathrm{cm}^{3} \mathrm{~g}^{-1}\right)\end{array}$ & $\begin{array}{l}\text { Pore diameter } \\
(\mathrm{nm})\end{array}$ \\
\hline \multicolumn{5}{|l|}{ Before SEWGS experiments } \\
\hline $30 \% \mathrm{Ni}-10 \% \mathrm{Co} \mathrm{HT}$ & $\mathrm{NiO}(3.8)$ & 175 & 0.6 & 11 \\
\hline $\mathrm{CaCeZr}$ & $\begin{array}{l}\mathrm{CaO}(40) \\
\mathrm{Ce}_{0.5} \mathrm{Zr}_{0.5} \mathrm{O}_{2}(10)\end{array}$ & 31.2 & 0.14 & --- \\
\hline \multicolumn{5}{|l|}{ After SEWGS experiments } \\
\hline Catalyst and sorbent mixture & $\begin{array}{l}\mathrm{NiO}(24) \\
\mathrm{CaO}(49) \\
\mathrm{Ce}_{0.5} \mathrm{Zr}_{0.5} \mathrm{O}_{2}(16) \\
\mathrm{CaZrO}_{3}(32)\end{array}$ & 12.1 & 0.05 & 15.9 \\
\hline
\end{tabular}




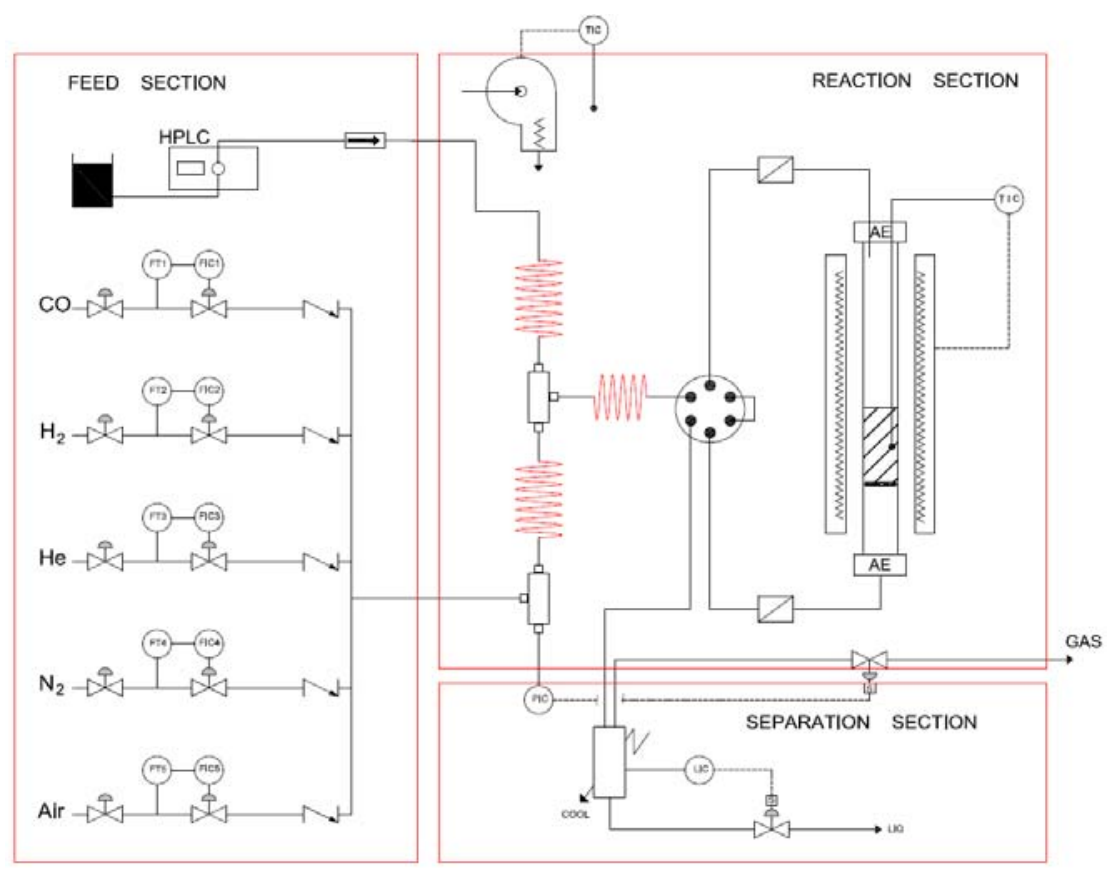

Fig. 1. Schematic flow diagram of the experimental setup used for SEWGS experiments. 


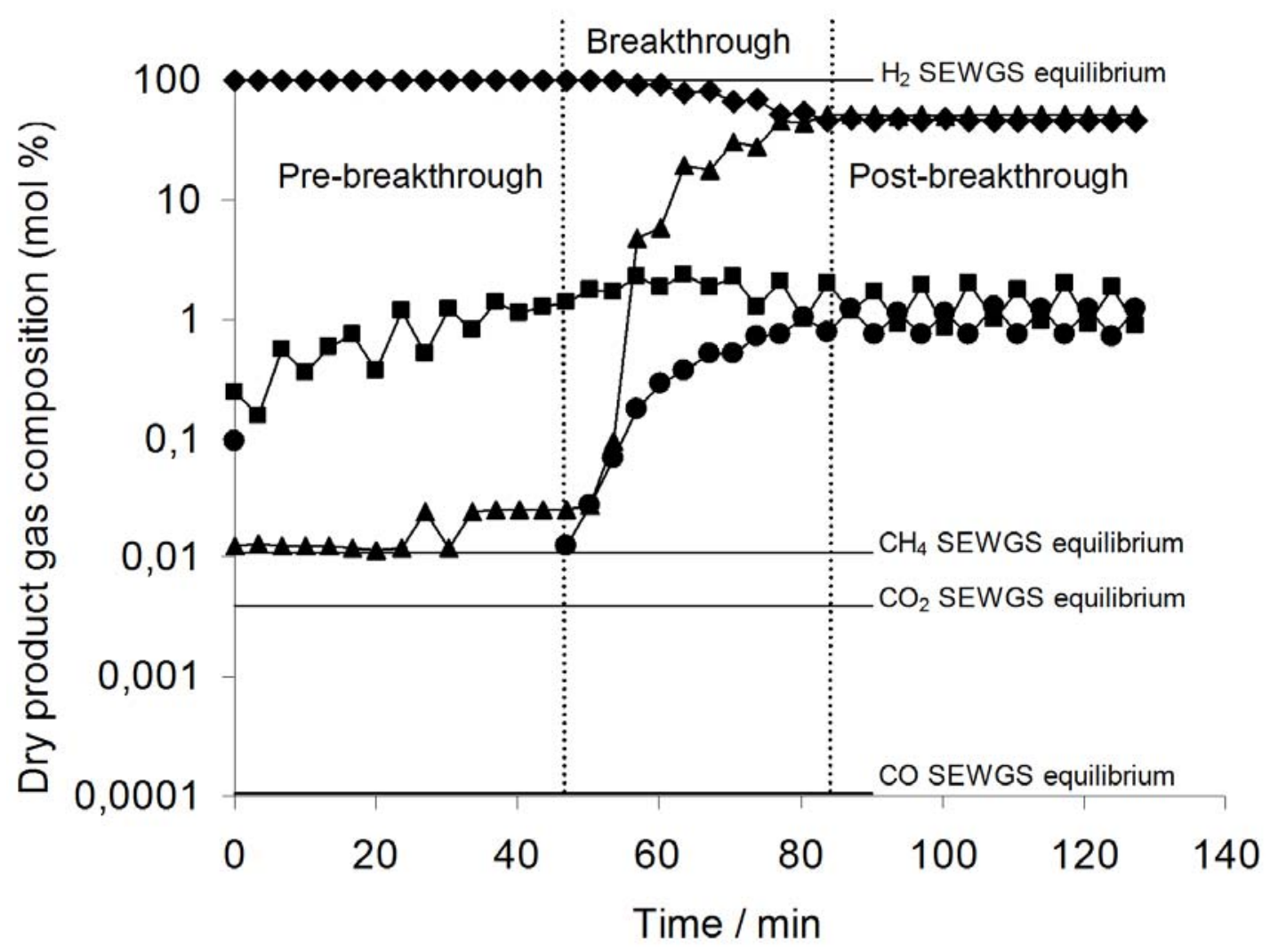

Fig. 2. Evolution of the product gas composition (dry basis; $\bullet \mathrm{H}_{2} ; \bullet \mathrm{CO}$; $\square \mathrm{CH}_{4}$; $\Delta \mathrm{CO}_{2}$ ) with time on stream during the SEWGS reaction. Reaction conditions: $425^{\circ} \mathrm{C}$, $1 \mathrm{~atm}$, steam $/ \mathrm{CO}=4 \mathrm{~mol} / \mathrm{mol}$, sorbent $/$ catalyst $=25 \mathrm{~g} / \mathrm{g}, \mathrm{CO}$ partial pressure in the feed stream $=6.25 \mathrm{kPa}, \mathrm{H}_{2} \mathrm{O}$ partial pressure in the feed stream $=25.00 \mathrm{kPa}, \mathrm{WHSV}=3.44 \mathrm{~h}^{-1}$, calcined dolomite as sorbent and $1 \% \mathrm{Pd} / 20 \% \mathrm{Ni}-20 \% \mathrm{Co}$ HT catalyst. 


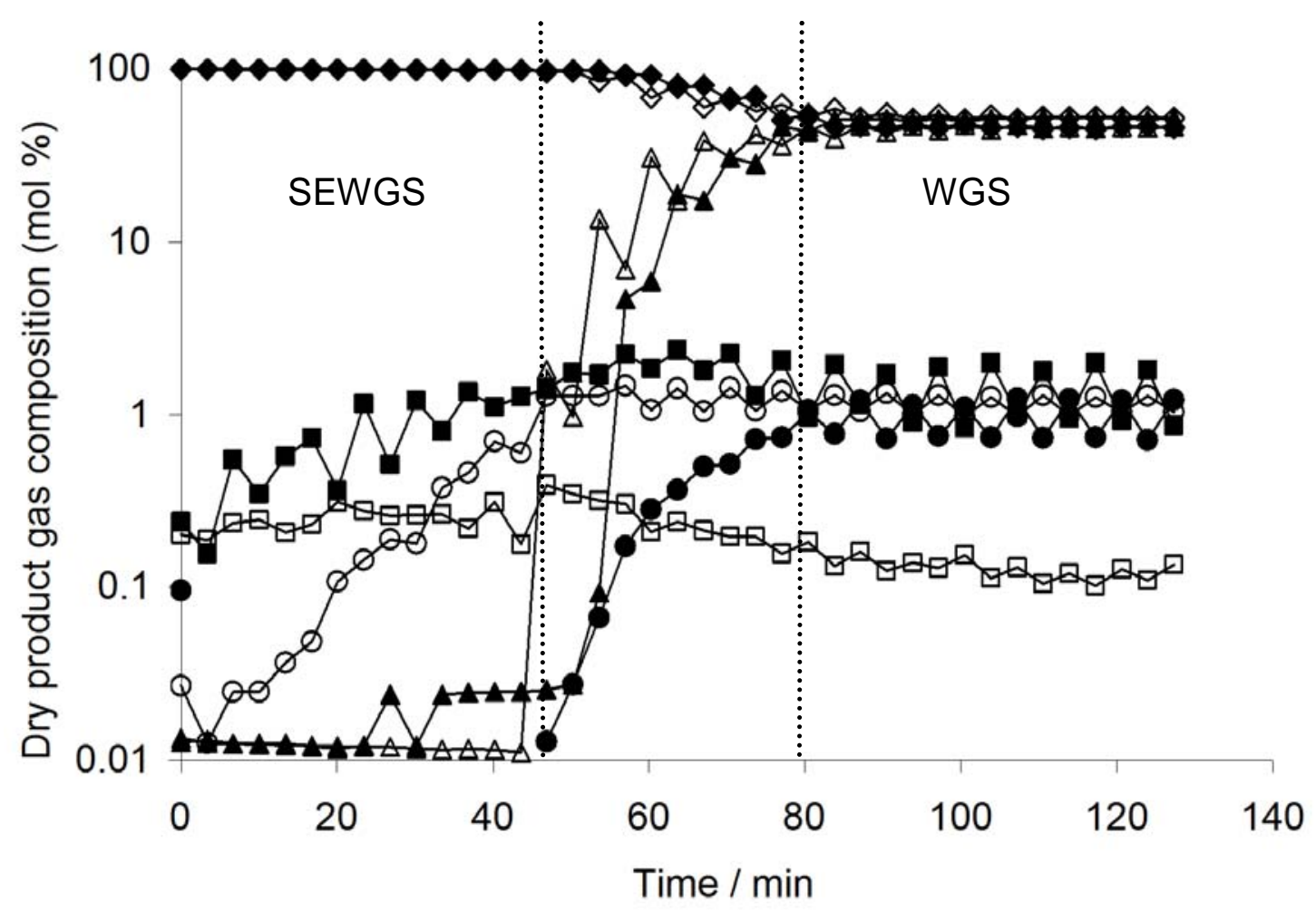

Fig. 3. Evolution of the product gas composition with time on stream during the SEWGS reaction using reduced and unreduced $1 \% \mathrm{Pd} / 20 \% \mathrm{Ni}-20 \% \mathrm{Co}$ HT catalyst (dry basis; $\bullet \mathrm{H}_{2}$-red; $\bullet \mathrm{CO}$-red; $\bullet \mathrm{CH}_{4}$-red; $\Delta \mathrm{CO}_{2}$-red; $\diamond \mathrm{H}_{2}$-unred; $\circ \mathrm{CO}$-unred; $\square \mathrm{CH}_{4}-$ unred; $\triangle \mathrm{CO}_{2}$-unred). Reaction conditions: $425^{\circ} \mathrm{C}, 1 \mathrm{~atm}, \quad$ steam $/ \mathrm{CO}=4 \mathrm{~mol} / \mathrm{mol}$, WHSV $=3.44 \mathrm{~h}^{-1}, \quad$ sorbent $/$ catalyst $=25 \mathrm{~g} / \mathrm{g}, \quad \mathrm{CO}$ partial pressure in the feed stream $=6.25 \mathrm{kPa}, \mathrm{H}_{2} \mathrm{O}$ partial pressure in the feed stream $=25.00 \mathrm{kPa}$ and calcined dolomite as sorbent. 


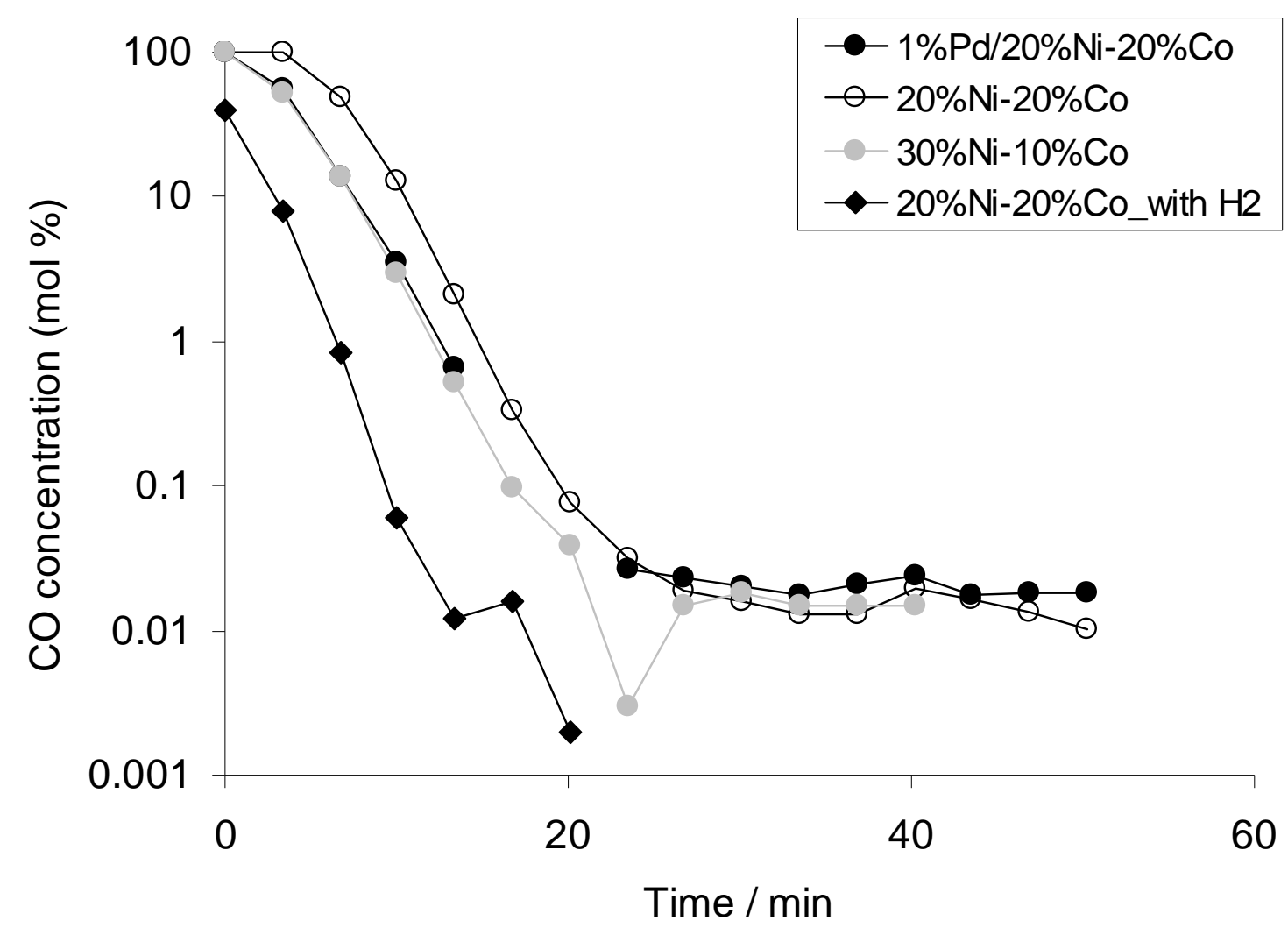

Fig. 4. Evolution of the $\mathrm{CO}$ concentration in the product gas with time on stream during the SEWGS reaction using catalysts with different metal composition (dry basis; $1 \% \mathrm{Pd} / 20 \% \mathrm{Ni}-20 \% \mathrm{Co} \mathrm{HT}$ and $\mathrm{P}_{\mathrm{CO}}=15.15 \mathrm{kPa}, \mathrm{P}_{\mathrm{H} 2 \mathrm{O}}=60.61 \mathrm{kPa} ; \circ 20 \% \mathrm{Ni}-20 \% \mathrm{Co} \mathrm{HT}$ and $\mathrm{P}_{\mathrm{CO}}=15.15 \mathrm{kPa}, \mathrm{P}_{\mathrm{H} 2 \mathrm{O}}=60.61 \mathrm{kPa} ; \quad 30 \% \mathrm{Ni}-10 \% \mathrm{Co} \quad \mathrm{HT}$ and $\mathrm{P}_{\mathrm{CO}}=15.15 \mathrm{kPa}$, $\mathrm{P}_{\mathrm{H} 2 \mathrm{O}}=60.61 \mathrm{kPa} ; \quad \cdot 20 \% \mathrm{Ni}-20 \% \mathrm{Co} \quad \mathrm{HT} \quad$ and $\mathrm{P}_{\mathrm{CO}}=12.20 \mathrm{kPa}, \quad \mathrm{P}_{\mathrm{H} 2 \mathrm{O}}=48.78 \mathrm{kPa}$, $\left.\mathrm{P}_{\mathrm{H} 2}=19.51 \mathrm{kPa}\right)$. Reaction conditions: $450{ }^{\circ} \mathrm{C}, \quad 1 \mathrm{~atm}, \quad$ steam $/ \mathrm{CO}=4 \mathrm{~mol} / \mathrm{mol}$, WHSV $=2.87 \mathrm{~h}^{-1}$, sorbent $/$ catalyst $=15 \mathrm{~g} / \mathrm{g}$ and calcined dolomite as sorbent. 


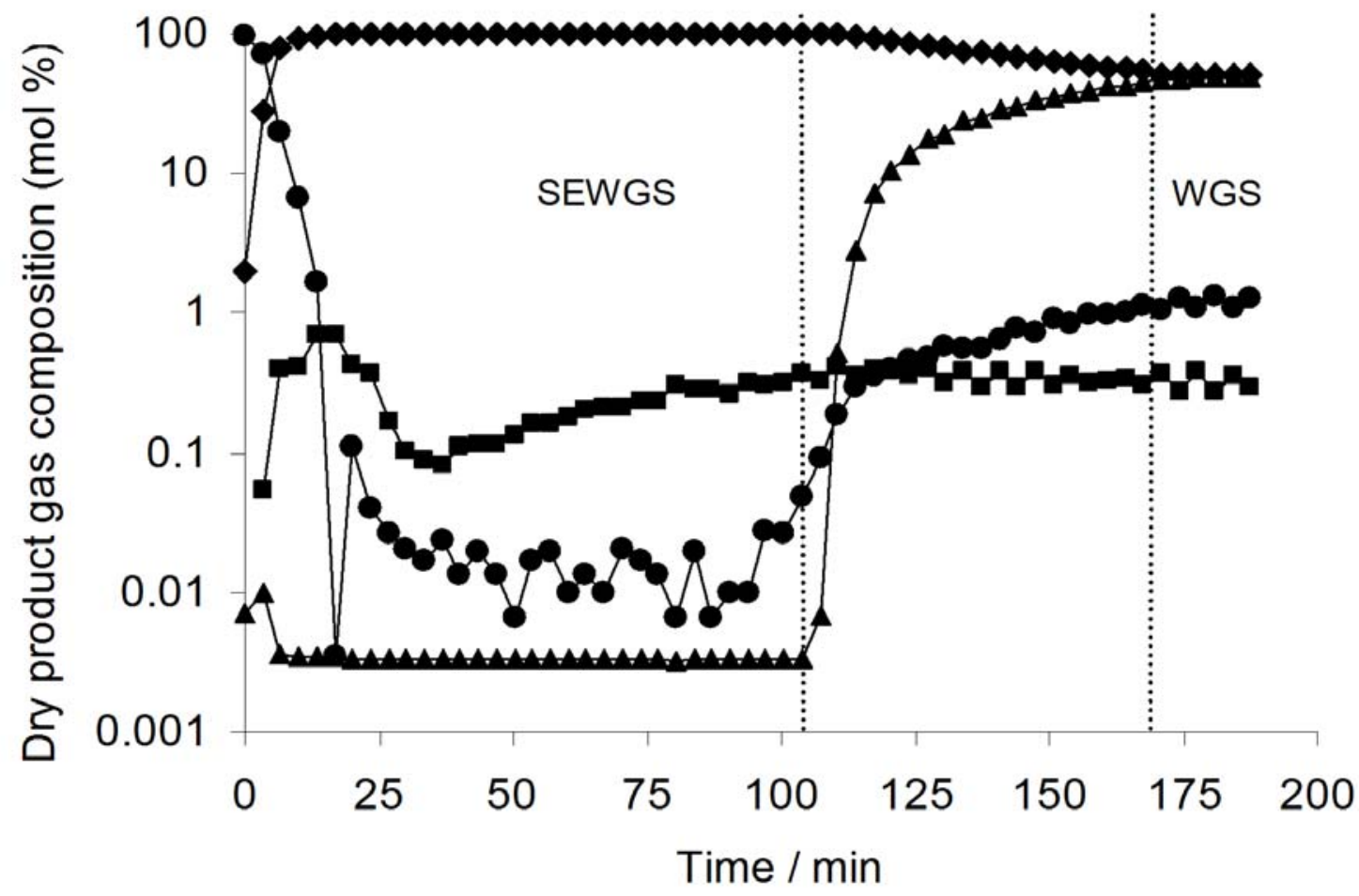

Fig. 5. Evolution of the product gas composition with time on stream during the first cycle of carbonation/decarbonation in the SEWGS process using CaCeZr (10:1:1) as sorbent (dry basis; $\bullet \mathrm{H}_{2} ; \bullet \mathrm{CO} ; \boldsymbol{\sim} \mathrm{CH}_{4} ; \boldsymbol{\Delta} \mathrm{CO}_{2}$ ). Reaction conditions: $450{ }^{\circ} \mathrm{C}, 1 \mathrm{~atm}$, steam $/ \mathrm{CO}=4 \mathrm{~mol} / \mathrm{mol}, \mathrm{WHSV}=2.29 \mathrm{~h}^{-1}$, sorbent $/$ catalyst $=20 \mathrm{~g} / \mathrm{g}, \mathrm{CO}$ partial pressure in the feed stream $=14.29 \mathrm{kPa}, \mathrm{H}_{2} \mathrm{O}$ partial pressure in the feed stream $=57.14 \mathrm{kPa}$ and $30 \% \mathrm{Ni}-10 \%$ Co HT catalyst. 


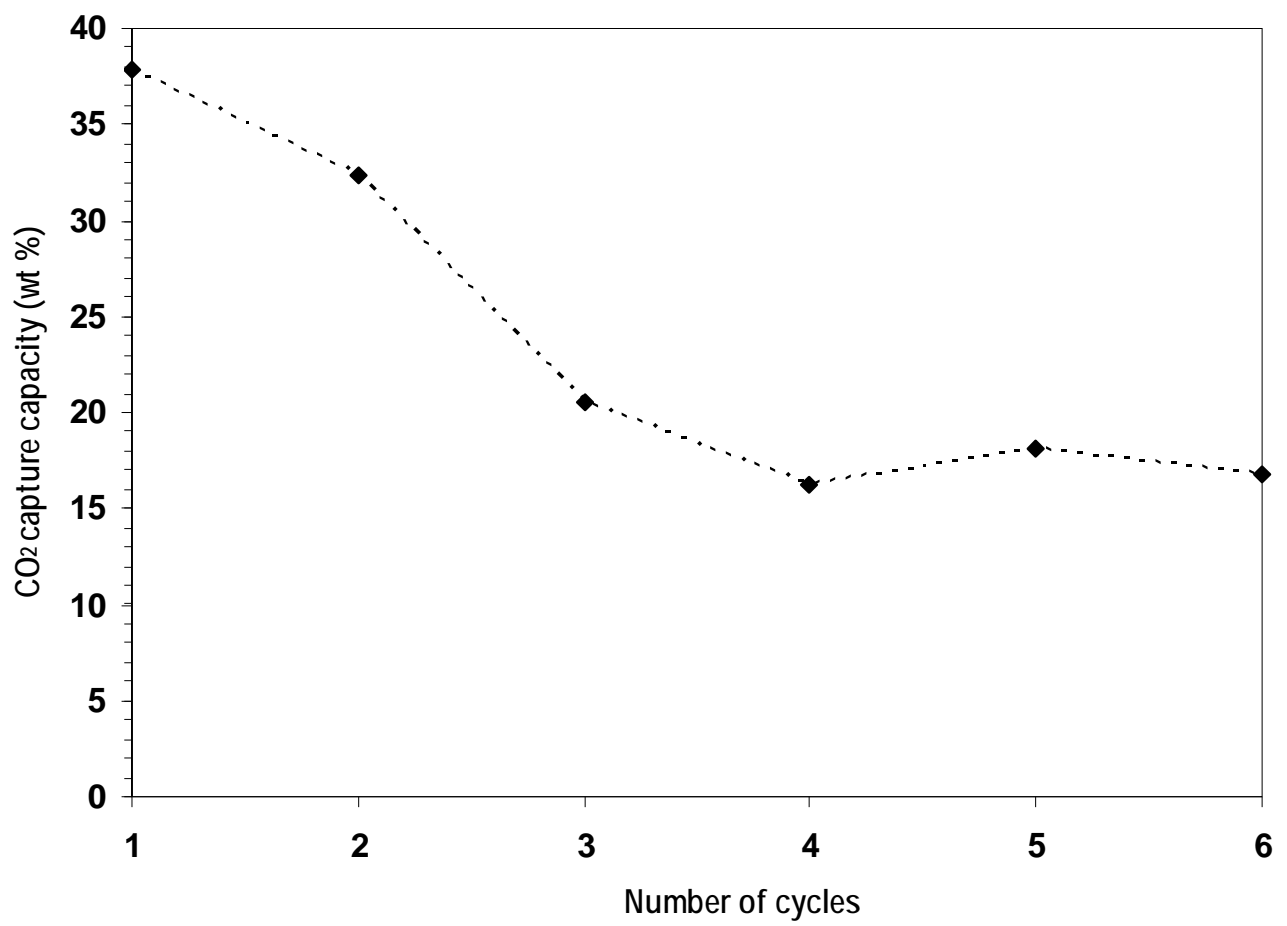

Fig. 6. In situ $\mathrm{CO}_{2}$ capture capacity of calcined $\mathrm{CaCeZr}(10: 1: 1)$ sorbent during the first six cycles of SEWGS reaction. Reaction conditions: $450{ }^{\circ} \mathrm{C}, 1 \mathrm{~atm}$, steam $/ \mathrm{CO}=4 \mathrm{~mol} / \mathrm{mol}, \mathrm{WHSV}=2.29 \mathrm{~h}^{-1}$ sorbent $/$ catalyst $=20 \mathrm{~g} / \mathrm{g}, \mathrm{CO}$ partial pressure in the feed stream $=14.29 \mathrm{kPa}, \mathrm{H}_{2} \mathrm{O}$ partial pressure in the feed stream $=57.14 \mathrm{kPa}$ and $30 \% \mathrm{Ni}-10 \% \mathrm{Co}$ HT catalyst. 


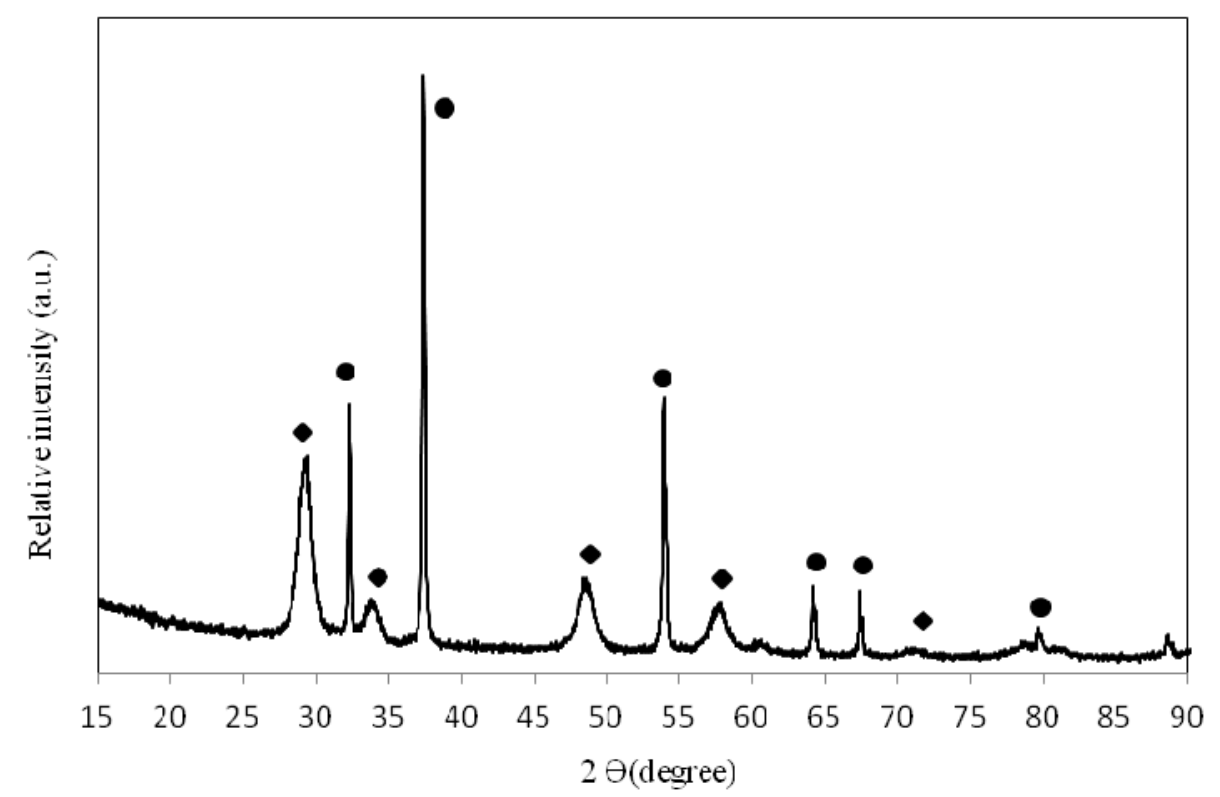

Fig. 7. XRD pattern of calcined $\mathrm{Ca}: \mathrm{Ce}: \mathrm{Zr}(10: 1: 1)$ mix oxide sorbent, $\mathrm{CaO}(\bullet)$, $\mathrm{Ce}_{0.5} \mathrm{Zr}_{0.5} \mathrm{O}_{2}(\bullet)$. 


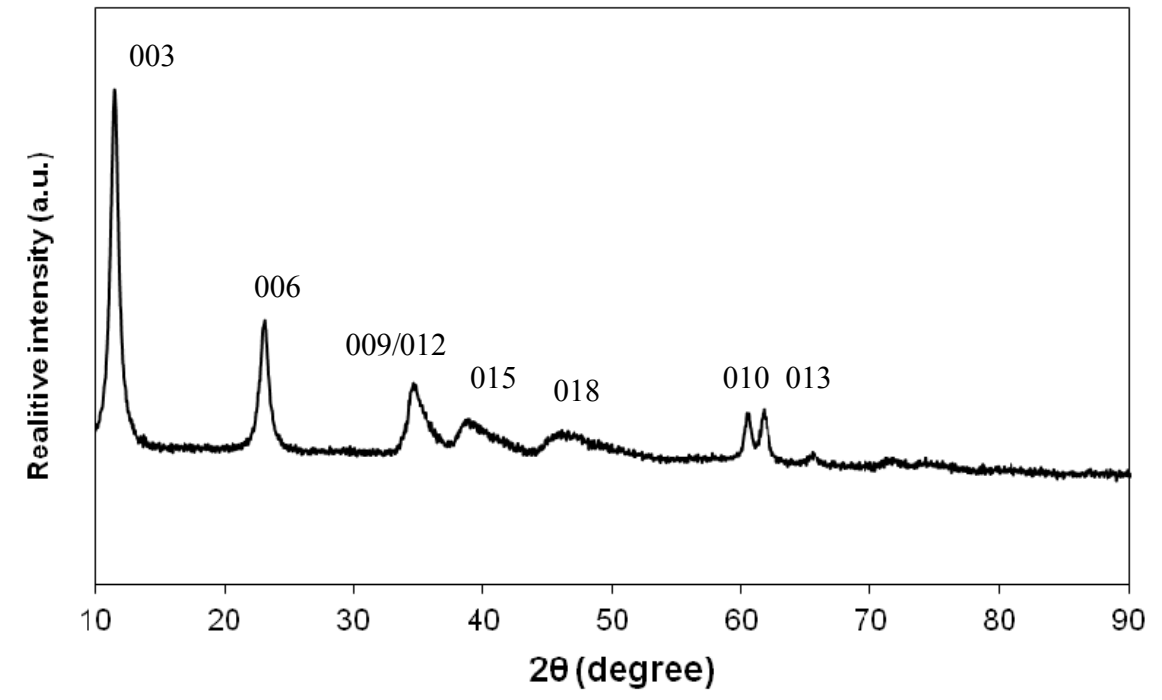

Fig. 8. XRD pattern of uncalcined $30 \% \mathrm{Ni}-10 \%$ Co hydrotalcite catalyst. 


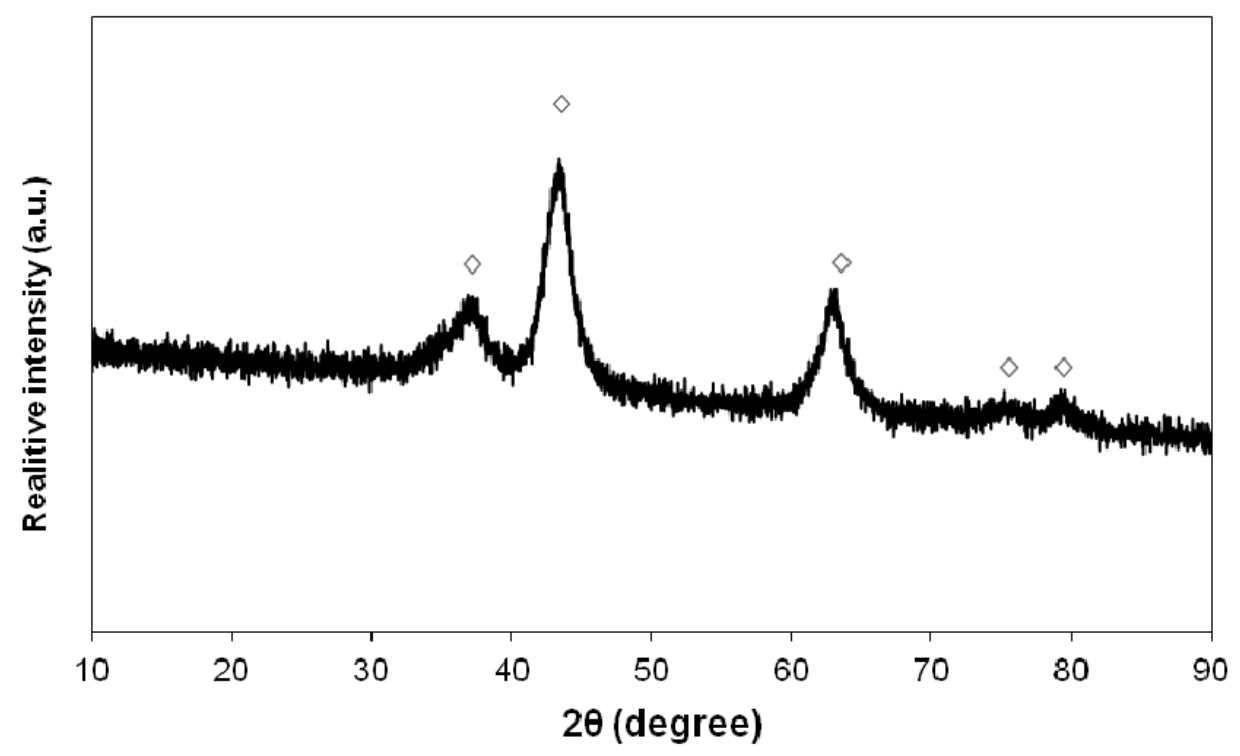

Fig. 9. XRD pattern of calcined $30 \% \mathrm{Ni}-10 \% \mathrm{Co}$ hydrotalcite catalyst. Peaks marked with $(\diamond)$ are characteristic of $\mathrm{NiO}, \mathrm{MgO}, \mathrm{MgNiO}_{2}, \mathrm{Co}_{3} \mathrm{O}_{4}, \mathrm{CoAl}_{2} \mathrm{O}_{4}, \mathrm{NiAl}_{2} \mathrm{O}_{4}, \mathrm{MgCo}_{2} \mathrm{O}_{4}$ and $\mathrm{Al}_{2} \mathrm{MgO}_{4}$. 


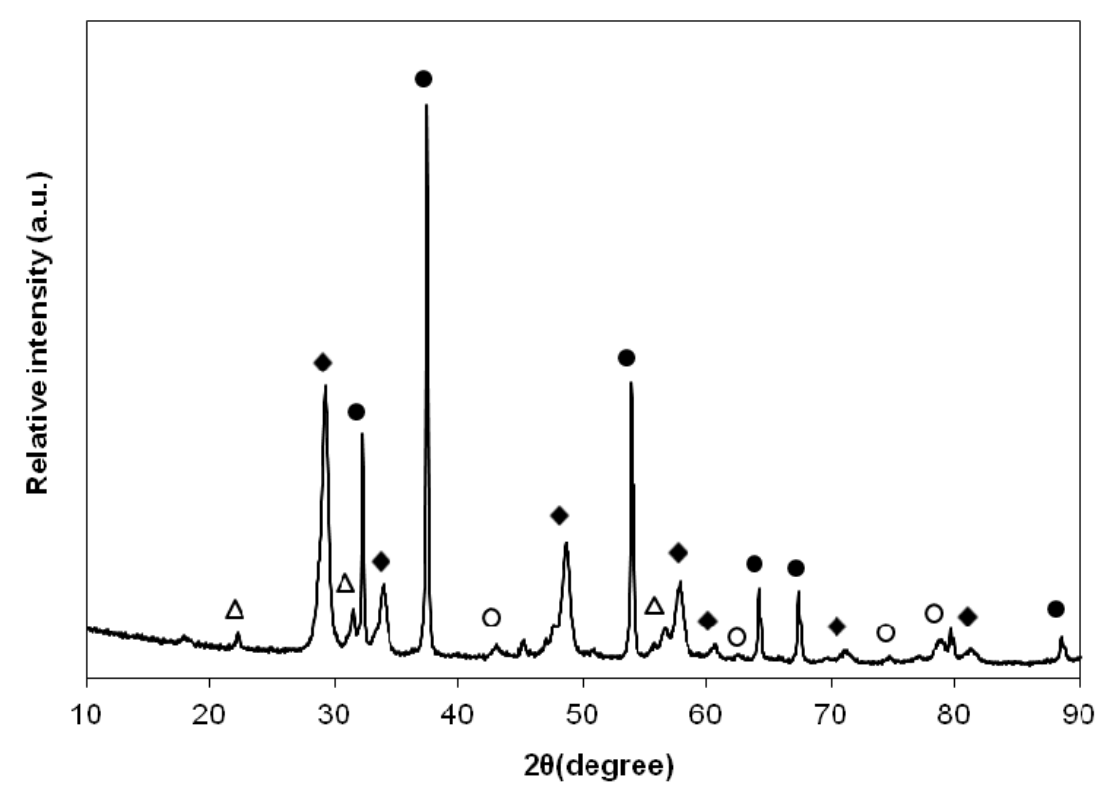

Fig. 10. XRD pattern of $\mathrm{CaCeZr}(10: 1: 1)$ and $30 \% \mathrm{Ni}-10 \% \mathrm{Co}$ hydrotalcite catalyst after seven cycles of SEWGS. $\mathrm{CaO}(\bullet), \mathrm{Ce}_{0.5} \mathrm{Zr}_{0.5} \mathrm{O}_{2}(\bullet) \mathrm{CaZrO}_{3}(\Delta) \mathrm{NiO}(\mathrm{O})$. 